\title{
ॠUSGS
}

science for a changing world

\section{Trends in Surface-Water Quality in Connecticut, 1989-98}

Water-Resources Investigations Report 02-4012

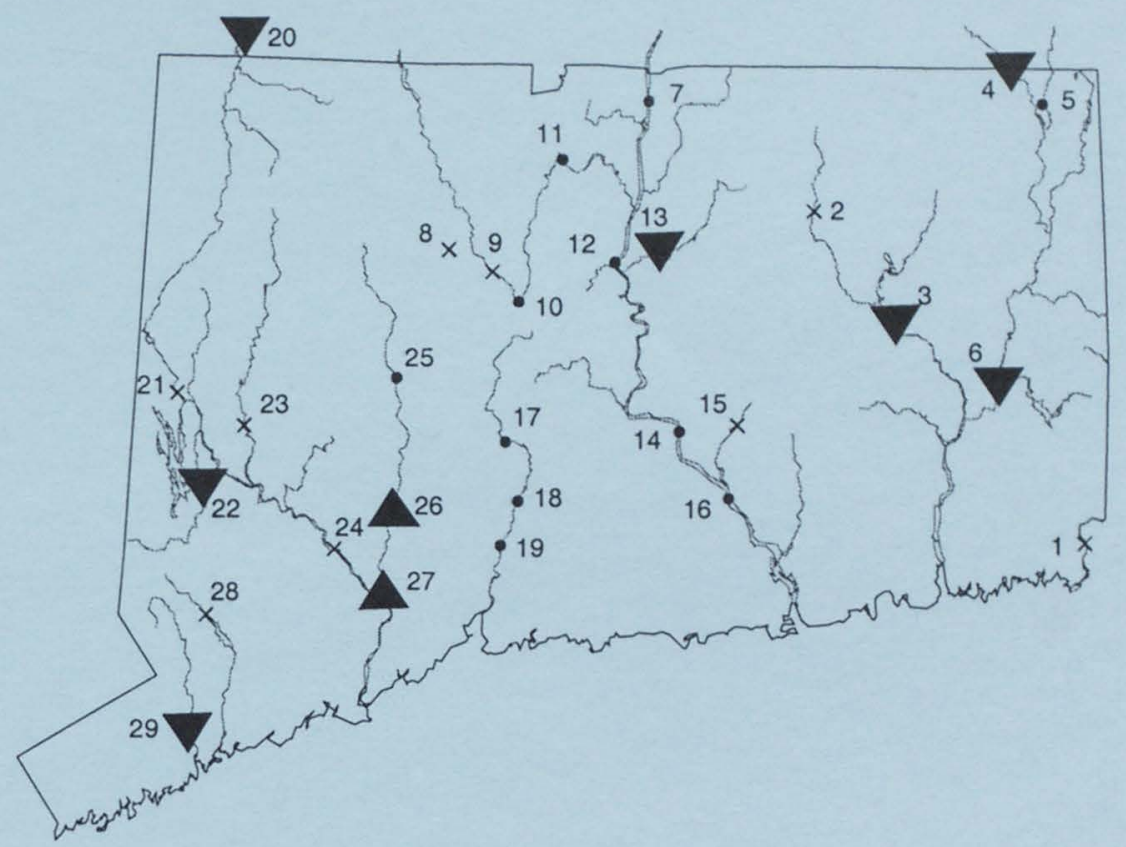

Prepared in cooperation with the Connecticut Department of Environmental Protection 
U.S. Department of the Interior

U.S. Geological Survey

\section{Trends in Surface-Water Quality in Connecticut, 1989-98}

By Michael J. Colombo and Elaine C. Todd Trench

Water-Resources Investigations Report 02-4012

Prepared in cooperation with the

Connecticut Department of Environmental Protection

East Hartford, Connecticut

2002 


\title{
U.S. DEPARTMENT OF THE INTERIOR \\ GALE A. NORTON, Secretary
}

\author{
U.S. GEOLOGICAL SURVEY
}

Charles G. Groat, Director

The use of firm, trade, and brand names in this report is for identification purposes only and does not constitute endorsement by the U.S. Government.

For additional information write to:

District Chief

U.S. Geological Survey

101 Pitkin Street

East Hartford, CT 06108

ct.water.usgs.gov
Copies of this report can be purchased from:

U.S. Geological Survey

Branch of Information Services

Box 25286, Federal Center

Denver, CO 80225 


\section{CONTENTS}

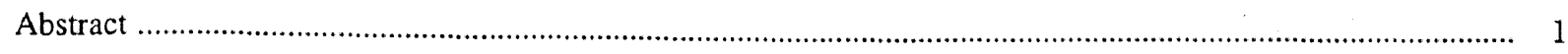

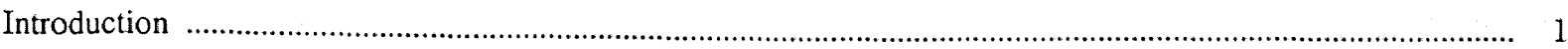

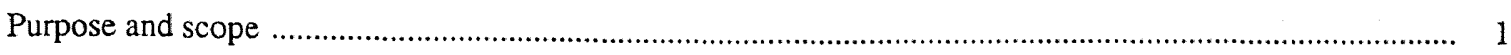

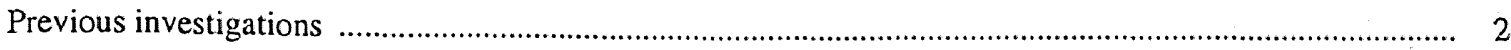

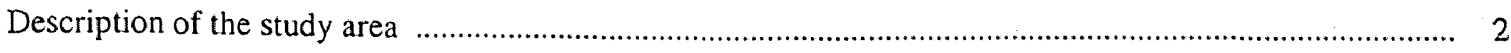

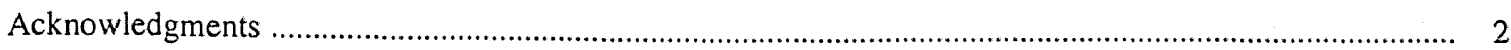

Data collection and trend analysis .................................................................................................... 3

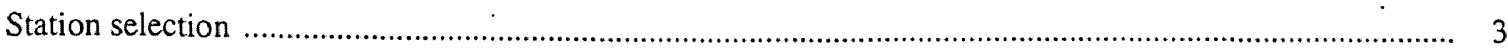

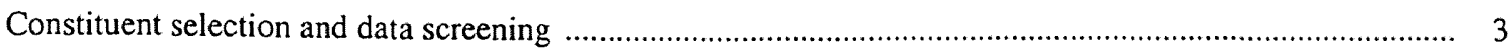

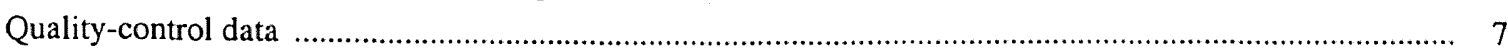

Effects of method changes on water-quality data ............................................................................ 8

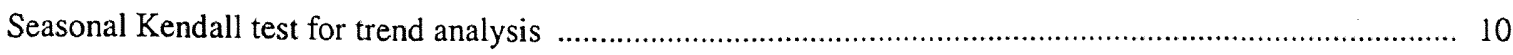

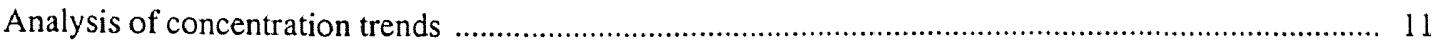

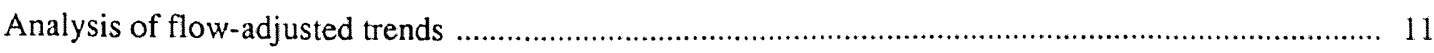

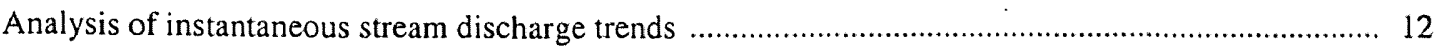

Trends in surface-water quality in Connecticut, 1989-98 .......................................................................... 12

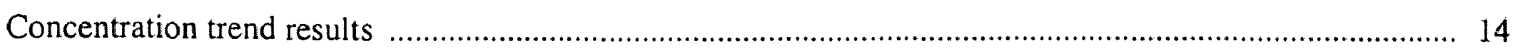

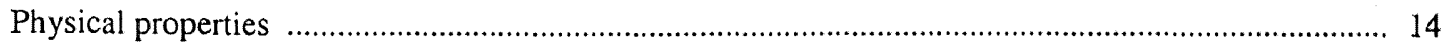

Major chemical constituents and related properties .............................................................. 14

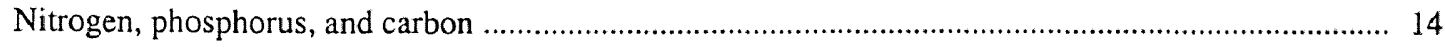

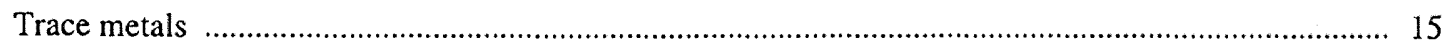

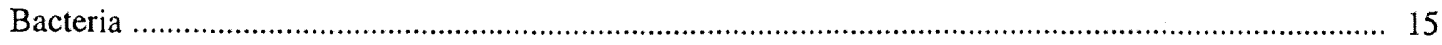

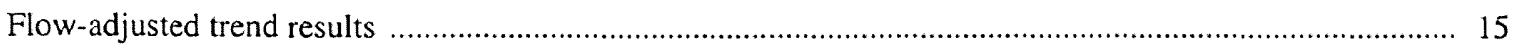

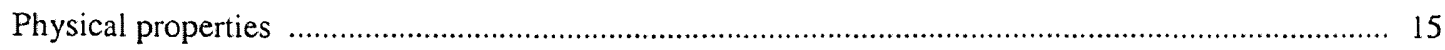

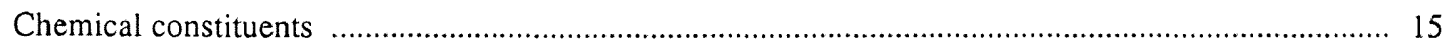

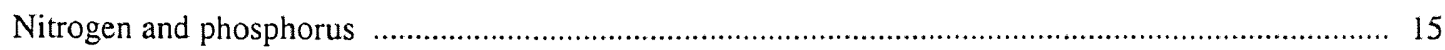

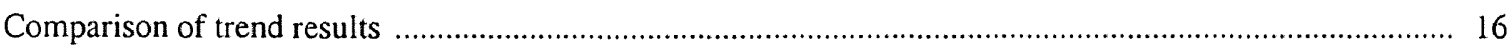

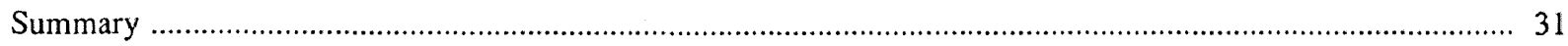

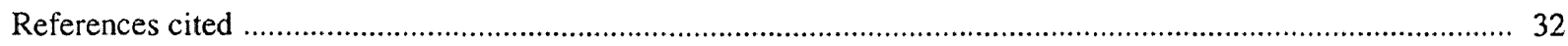

Appendix 1. Summary of trends for physical properties and major chemical constituents, 1989-98 _................... 37

Appendix 2. Summary of trends for trace metals, nutrients, and bacteria, 1989-98 …..................................... 38

Appendix 3. Summary of flow-adjusted trends for selected water-quality constituents, 1989-98 _....................... 39

\section{FIGURES}

1. Map showing location of water-quality monitoring stations selected for trends, 1989-98 _.................... 6

2. Scatterplot showing effects of changes in methods for sample collection, processing, and analysis for dissolved zinc, Quinebaug River at Quinebaug, Conn., 1989-98 
Figures 3. - 25. Maps showing trends in:

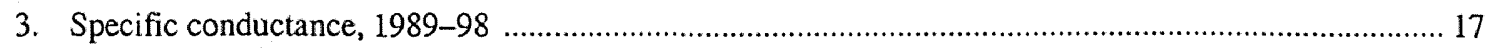

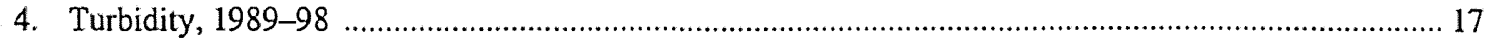

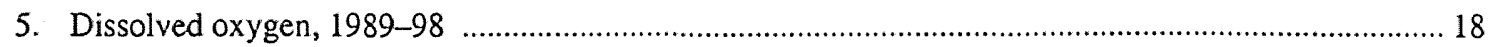

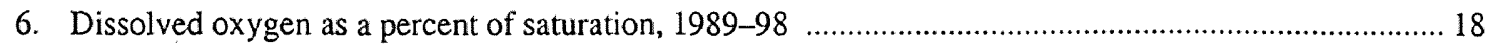

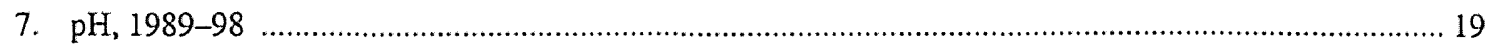

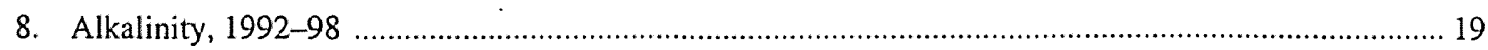

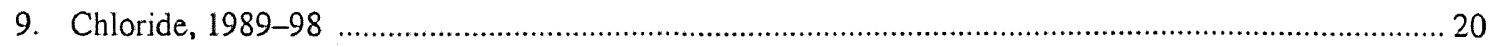

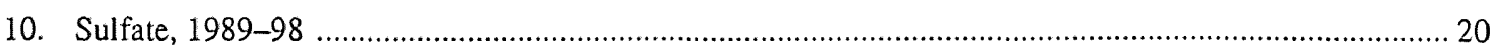

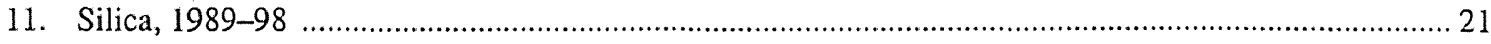

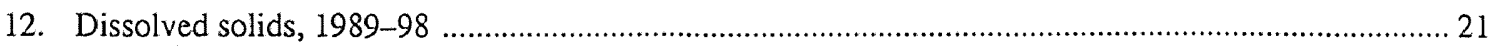

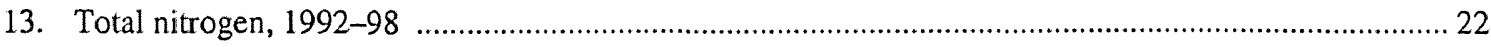

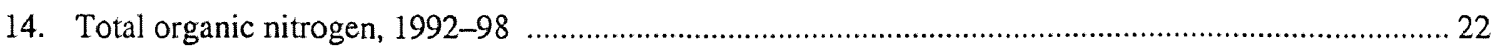

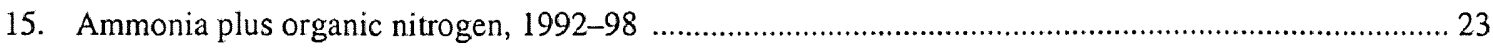

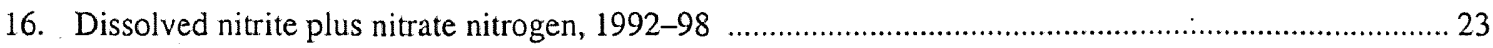

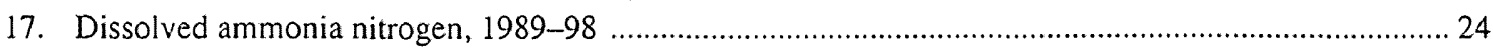

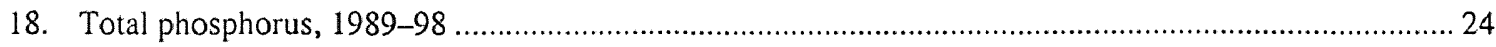

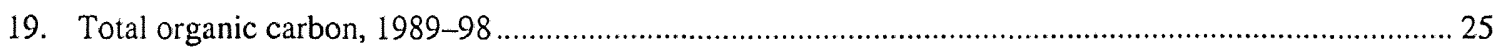

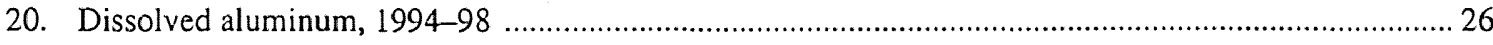

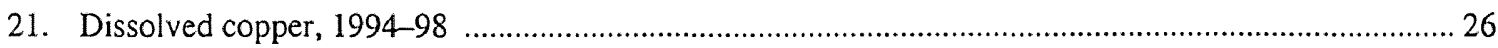

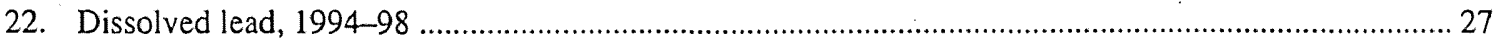

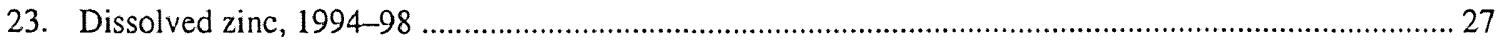

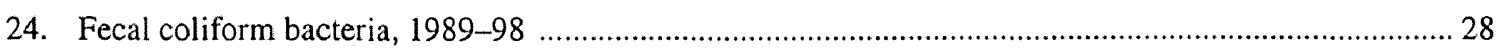

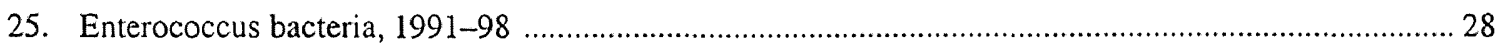

Figures 26. - 30. Maps showing flow-adjusted trends in:

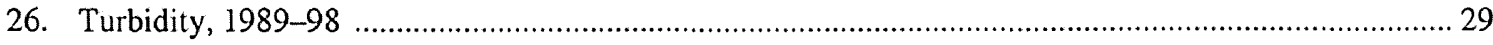

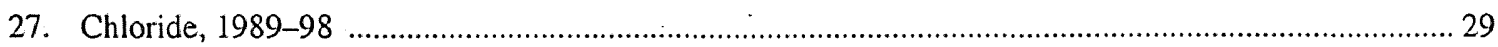

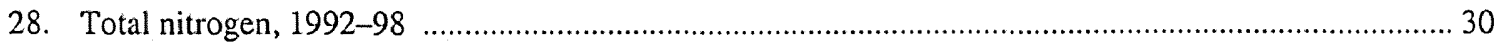

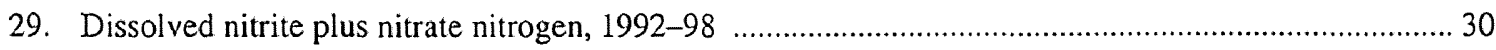

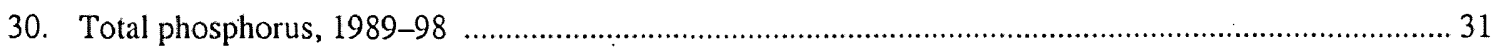

\section{TABLES}

1. Water-quality monitoring stations selected for trend analysis in Connecticut, 1989-98 ...........................

2. Water-quality constituents and properties selected for trend analysis in Connecticut, 1989-98 ................. 7

3. Statewide summary of statistically significant trends in water quality at selected stations in Connecticut, water years 1989-98

4. Summary of the most prevalent concentration trends in water quality in Connecticut, water years $1975-88$ and $1989-98$ 


\section{CONVERSION FACTORS AND ABBREVIATIONS}

\begin{tabular}{rcl}
\hline Multiply & \multicolumn{1}{c}{ By } & To obtain \\
\hline inch (in.) & 25.4 & millimeter \\
mile (mi) & 1.609 & kilometer \\
square mile $\left(\mathrm{mi}^{2}\right)$ & 2.590 & square kilometer \\
\hline
\end{tabular}

Temperature in degrees Celsius $\left({ }^{\circ} \mathrm{C}\right)$ may be converted to degrees Fahrenheit $\left({ }^{\circ} \mathrm{F}\right)$ as follows:

${ }^{\circ} \mathrm{F}=\left(1.8 \times{ }^{\circ} \mathrm{C}\right)+32$

Concentrations of chemical constituents in water are given in milligrams per liter $(\mathrm{mg} / \mathrm{L})$ and micrograms per liter $(\mu \mathrm{g} / \mathrm{L})$.

Concentrations of indicator bacteria are given in colonies per 100 milliliters $(\mathrm{mL})$ of sample. 


\title{
Trends in Surface-Water Quality in Connecticut, 1989-98
}

\author{
by Michael J. Colombo and Elaine $\mathrm{C}$. Todd Trench
}

\section{ABSTRACT}

Trends in surface-water quality at 29 stations were analyzed for the 1989-98 water years. Trend results for 22 properties and constituents are reported in summary tables and maps that show statewide coverage of individual waterquality properties or constituents. Statewide results indicate scattered statistically significant upward or downward trends for most waterquality constituents or properties. Areawide changes in water quality are indicated by upward trends in chloride (median trend slope at 9 stations was $0.5 \mathrm{mg} / \mathrm{L} /$ year), dissolved solids (median trend slope at 6 stations was $1.2 \mathrm{mg} / \mathrm{L} /$ year), and fecal coliform (median trend slope at 5 stations was 72 colonies/ $100 \mathrm{~mL} /$ year), as well as downward trends in sulfate (median trend slope at 23 stations was $-0.3 \mathrm{mg} / \mathrm{L} /$ year), alkalinity (median trend slope at 10 stations was $-1.2 \mathrm{mg} / \mathrm{L} / \mathrm{year}$ ), and phosphorus (median trend slope at 7 stations was $-0.003 \mathrm{mg} / \mathrm{L} /$ year).

Values of specific conductance and concentrations of chloride and dissolved solids continued the upward trend detected in an earlier study period of 1975-88, while phosphorus continued to trend downward. Differences can be noted in results for turbidity and fecal coliform bacteria, both of which had downward trends during 197588 and upward trends during 1989-98. Upward trends in sulfate were detected during 1975-82; however, downward trends were widespread during 1989-98. In contrast to upward nitrogen trends statewide for the 1975-88 study, no current statewide trends were found for nitrogen constituents.

Trends were analyzed using the nonparametric seasonal Kendall test. Five constituents at nine stations were adjusted for flow by analyzing residuals from regression analysis for trend. Understanding data selection, changes in sample collection, and changes in laboratory analysis methods enables one to differentiate between trends that reflect effects of new methods or technology and trends caused by environmental changes.

\section{INTRODUCTION}

A trend in surface-water quality is a change over time in the biological, chemical, or physical characteristics of the water. Identification of water-quality trends is useful in targeting areas for further study, investigating possible causes of changes in water quality, planning remediation of water-quality problems, and evaluating effects of remediation.

The U.S. Geological Survey (USGS) and the Connecticut Department of Environmental Protection (DEP) have worked together during the last three decades to monitor water-quality conditions in Connecticut. The long-term cooperative program between USGS and the DEP has provided a substantial database of water-quality records that can be used for trend analysis. The data from this network are suitable for a statewide trend study on a number of different physical properties, chemical constituents, and bacteria. In 1998, the USGS and the Connecticut DEP began a cooperative project to assess recent trends in surface-water quality in Connecticut.

\section{Purpose and Scope}

This report presents the results of analysis of trends in surface-water-quality data for 22 constituents at 29 stations in Connecticut during 1989-98. The report also describes how the data were selected and screened for trend analysis, summarizes the statistical procedures used, and presents the findings in tables and maps. The 29 water-quality stations evaluated in this study cover all major basins in Connecticut. 


\section{Previous Investigations}

Several previous USGS studies have investigated trends in surface-water quality. Smith and others (1982) analyzed trends in total phosphorus concentrations at National Stream Quality Accounting Network stations throughout the United States using the seasonal Kendall test. The test was applied to concentration values and flow-adjusted concentrations. Smith and others (1987) analyzed and interpreted waterquality trends in major rivers across the U.S. This study evaluated 24 water-quality constituents at more than 300 sites and detected trends that indicate both improvement and deterioration in water quality. Changes in water quality appeared to be in response to changes in atmospheric and terrestrial inputs to surface waters.

Schertz (1990) modified methods from national trend studies to analyze trends in streamwater quality in Texas. Data, trends, and ancillary data were examined to determine possible causes of trends. The study also included the evaluation and supporting documentation of methods for trend analysis of large, complicated databases (Schertz and others, 1991). Other statewide trends studies using similar methods have been done in New Jersey (Hay and Campbell, 1990) and Arkansas (Petersen, 1992). More recently, Mast and Turk (1999) described water-quality trends at 16 basins that are minimally affected by human activities in the eastern United States.

Trends in surface-water quality in Connecticut during 1969-88 were analyzed for 29 physical properties, chemical constituents, and bacteriological constituents (Trench, 1996). Eight stations were analyzed for long-term trends (1969-88), 35 stations for mediumterm trends (1975-88), and 38 stations for short-term trends (1981-88). The seasonal Kendall test was used to detect trends in unadjusted concentrations and flowadjusted concentrations. The report indicated that trends may have been caused by several factors, including changes in land cover and land use, urbanization, wastewater-treatment improvements, nonpointsource pollution runoff, atmospheric deposition, or combinations of these factors.

\section{Description of the Study Area}

Connecticut is the second smallest state in New England with an area of $5,009 \mathrm{mi}^{2}$. Connecticut is bounded by Rhode Island to the east, Massachusetts to the north, New York to the west, and Long Island Sound to the south.

The climate in Connecticut is generally temperate and humid, and average monthly precipitation is evenly distributed throughout the year. Median annual precipitation for calendar years 1989-98 was 46.18 in. at Hartford Weather Station Office (Airport). Yearly totals ranged from 37.75 in. in 1997 to 55.18 in. in 1996 (National Oceanic and Atmospheric Administration, 1990-99). Streamflow varies considerably throughout the year in response to precipitation and snowmelt. High-flow conditions generally are in spring, and low-flow conditions generally are in late summer or early fall; however, major flooding can take place any time of year.

Much of the bedrock in Connecticut is metamorphic and igneous noncarbonate crystalline rock (Rodgers, 1985). The crystalline rock is composed of relatively insoluble silicate materials, which leads to water with naturally low concentrations of dissolved ions. The central lowland, which bisects the State and extends from west-central Massachusetts to Long Island Sound, is primarily sedimentary and igneous rock. Connecticut was glaciated approximately 18,000 years ago, and glacial till and stratified deposits cover most of the State.

The population of the State decreased slightly from 3.287 million in 1990 to 3.273 million in 1998 . Connecricut ranked fourth of the 50 states in population density in 1990 (U.S. Bureau of the Census, 1999). The most densely populated (more than 1,500 persons per square mile) urban areas coincide with the central valley and the southwestern coastal areas. Historic land-use development and the current pattern of land use throughout the State are important to understanding the spatial and temporal changes in water quality (Zimmerman and others, 1996, p. 5). In 1998, land use in Connecticut was 59 percent forested, 20 percent urban, 10 percent agricultural, and 11 percent water and other land uses (Vogelmann and others, 1998).

\section{Acknowledgments}

The authors would like to thank the following USGS personnel: Jonathan Morrison for an explanation of historical water-quality data of Connecticut, Merritt Blalock for scripts to handle assembly of data files used for trend analysis, John Mullaney for help with graphical representation of trend results, and Terry 
Schertz for insight and comments regarding use of quality-assurance data as it pertains to trend analysis of statewide water-quality data. The authors also thank Barbara Korzendorfer for her assistance in the production of the manuscript and David Mau and Lori Sprague for technical reviews of the report.

\section{DATA COLLECTION AND TREND ANALYSIS}

Trends in surface-water quality for 22 properties and constituents at 29 stations were analyzed for the 1989-98 water years ${ }^{1}$. Data were analyzed using the seasonal Kendall test, a nonparametric test for trends in water quality developed by Hirsch and others (1982). Strengths of the seasonal Kendall test include application to non-normal data, use on censored or missing data, and application for analyzing regional-scale projects with numerous stations and constituents. Water-quality data can be retrieved through the National Water-Information System website (NWISWeb) at http://water.usgs.gov/ct/nwis/ and compared to data in this report using parameter codes (P-codes) and station identification numbers.

\section{Station Selection}

The Connecticut surface-water-quality network has undergone numerous changes in the number and location of stations in response to needs of cooperators, new projects, water-quality issues, and financial constraints. The network consisted of 7 stations when it was initiated in 1967, increased to 45 stations in 1976, decreased to 30 stations in 1992 , and increased to 34 stations in 1998.

This study includes data from 29 stations where water-quality samples were collected for all or part of the water years from 1989-98 (table 1). These stations represent all major drainage basins in the State

(fig. 1)-5 stations in the Thames River Basin, 10 in the Connecticut River Basin, 8 in the Housatonic River Basin, and 6 in basins that drain coastal areas. Twentyfive stations have water-quality records from the entire study period (1989-98). One station-Still River at

\footnotetext{
'A water year is the 12 -month period October I through September 30 and is designated by the calendar year in which it ends; thus the year from October 1, 1997 through September 30, 1998 is called the 1998 water year.
}

Brookfield, Conn. (01201487)-is missing water year 1992. Three stations-French River at North Grosvenordale, Conn. (01125100), Hockanum River at East Hartford, Conn. (01192500), and Housatonic River near Ashley Falls, Mass. (01198125) - have shorter periods of record (1992-98) (table 1).

Locations and station identification numbers for two stations changed during the period of record - the Farmington River at Unionville was relocated from 01188085 (1974-83) to 01188090 (1984-98), and the Still River at Brookfield Center was relocated from 01201485 (1974-83) to 01201487 (1984-98). These two stations were moved from their original locations because of sampling logistics. Further investigation may be necessary to compare water-quality trends detected at these stations in the present study to earlier trends reported under former station numbers (Trench, 1996).

\section{Constituent Selection and Data Screening}

The 22 constituents examined for this study' include physical properties, major chemical constituents, nutrients, trace metals, and bacteria (table 2). At least 5 years of record, with minimal gaps, and more than 25 samples are necessary to accurately assess a trend in water quality. Each station used in this study had 10 years of record and more than 40 samples.

Sampling for several constituents was begun or discontinued during the study period; therefore, several constituents have too few data points at some stations for a valid trend analysis. These constituents are shown in appendix 1 or 2 as " $\mathrm{m}$ " (more than 25 percent of the data are missing). Missing data may result from a different period of record for a particular constituent at a station. Only regular network samples were used to analyze trends at the 29 stations. Any data collected for other studies at these sites were excluded in order to achieve a consistent sampling frequency throughout the 10-year study period. Data on surface-water quality and surface-water discharge used in this trend analysis were published previously in the series of annual data reports of the U.S. Geological Survey entitled "Water Resources Data-Connecticut," for water years 1989-98 (Cervione and others, 1990-93; Davies and others, 1994-99). 
- Table 1. Water-quality monitoring stations in Connecticut selected for trend analysis, 1989-98

${ }^{*}$, tidal nonsaline]

\begin{tabular}{|c|c|c|c|c|c|c|c|c|}
\hline $\begin{array}{c}\text { Map } \\
\text { reference } \\
\text { number } \\
\text { (shown on } \\
\text { fig. 1) }\end{array}$ & $\begin{array}{l}\text { Station } \\
\text { number }\end{array}$ & Station name and location & $\begin{array}{l}\text { Hydrologic } \\
\text { unit code }\end{array}$ & $\begin{array}{l}\text { Drainage } \\
\text { area } \\
\text { (square } \\
\text { miles) }\end{array}$ & Latitude & Longitude & $\begin{array}{l}\text { Period of } \\
\text { record } \\
\text { (water } \\
\text { years) }\end{array}$ & $\begin{array}{l}\text { Sampling } \\
\text { frequency } \\
\text { (number of } \\
\text { samples per } \\
\text { year used in } \\
\text { the analysis) }\end{array}$ \\
\hline 1 & 01118500 & Pawcatuck River at Westerly, R.I. & 01090005 & 295 & $41^{\circ} 2301^{\prime \prime}$ & $71^{\circ} 5001 "$ & $1976-98$ & 4 \\
\hline 2 & 01119375 & Willimantic River at Merrow, Conn. & 01100002 & 94.0 & $41^{\circ} 500^{\prime} 07^{\prime \prime}$ & $72^{\circ} 18^{\prime} 38^{\prime \prime}$ & $1974-98$ & 8 \\
\hline 3 & 01122610 & Shetucket River at South Windham, Conn. & 01100002 & 408 & $41^{\circ} 40^{\prime} 56^{\prime \prime}$ & $72^{\circ} 09^{\prime} 59^{\prime \prime}$ & $1974-98$ & 8 \\
\hline 4 & 01124000 & Quinebaug River at Quinebaug, Conn. & 01100001 & 155 & $42^{\circ} 01^{\prime} 20^{\prime \prime}$ & $71^{\circ} 57^{\prime} 22^{\prime \prime}$ & $1981-98$ & 8 \\
\hline 5 & 01125100 & French River at North Grosvenordale, Conn. & 01100001 & 101 & $41^{\circ} 58^{\prime} 41^{\prime \prime}$ & $71^{\circ} 54^{\prime} 03^{\prime \prime}$ & $1992-98$ & 8 \\
\hline 6 & 01127000 & Quinebaug River at Jewett City, Conn. & 01100001 & 713 & $41^{\circ} 35^{\prime} 52^{\prime \prime}$ & $71^{\circ} 59^{\prime} 05^{\prime \prime}$ & $1968-98$ & 8 \\
\hline 7 & 01184000 & Connecticut River at Thompsonville, Conn. & 01080205 & 9,660 & $41^{\circ} 59^{\prime} 14^{\prime \prime}$ & $72^{\circ} 36^{\prime} 21^{\prime \prime}$ & $1966-98$ & 12 \\
\hline 8 & 01188000 & Burlington Brook near Burlington, Conn. & 01080207 & 4.10 & $41^{\circ} 47^{\prime} 10^{\prime \prime}$ & $72^{\circ} 57^{\prime} 55^{\prime \prime}$ & $1968-98$ & 4 \\
\hline 9 & 01188090 & $\begin{array}{l}\text { Farmington River, at Route } 4 \text {, } \\
\text { at Unionville, Conn. }\end{array}$ & 01080207 & 374 & $41^{\circ} 45^{\prime} 52^{\prime \prime}$ & $72^{\circ} 53^{\prime} 47^{\prime \prime}$ & $1974-98$ & 8 \\
\hline 10 & 01189030 & Pequabuck River at Farmington, Conn. & 01080207 & 57.2 & $41^{\circ} 43^{\prime} 00^{\prime \prime}$ & $72^{\circ} 50^{\prime} 25^{\prime \prime}$ & $1974-98$ & 4 \\
\hline 11 & 01189995 & Farmington River at Tariffville, Conn. & 01080207 & 577 & $41^{\circ} 54^{\prime} 30^{\prime \prime}$ & $72^{\circ} 45^{\prime} 40^{\prime \prime}$ & $1971-98$ & 8 \\
\hline 12 & 01190070 & Connecticut River at Hartford, Conn.* & 01080205 & 10,487 & $41^{\circ} 46^{\prime} 00^{\prime \prime}$ & $72^{\circ} 400^{\prime} 04^{\prime \prime}$ & $1977-98$ & 6 \\
\hline 13 & 01192500 & Hockanum River at East Hartford, Conn. & 01080205 & 73.4 & $41^{\circ} 46^{\prime} 59^{\prime \prime}$ & $72^{\circ} 35^{\prime} 16^{\prime \prime}$ & $1992-98$ & 6 \\
\hline 14 & 01193050 & Connecticut River at Middle Haddam, Conn.* & 01080205 & 10,897 & $41^{\circ} 32^{\prime} 30^{\prime \prime}$ & $72^{\circ} 33^{\prime} 13^{\prime \prime}$ & $1967-98$ & 6 \\
\hline 15 & 01193500 & Salmon River near East Hampton, Conn. & 01080205 & 100 & $41^{\circ} 33^{\prime} 08^{\prime \prime}$ & $72^{\circ} 26^{\prime} 59^{\prime \prime}$ & $1968-98$ & 8 \\
\hline 16 & 01193750 & Connecticut River at East Haddam, Conn.* & 01080205 & 11,092 & $41^{\circ} 27^{\prime} 05^{\prime \prime}$ & $72^{\circ} 27 ' 55^{\prime \prime}$ & 1974-98 & 4 \\
\hline 17 & 01196222 & Quinnipiac River near Meriden, Conn. & 01100004 & 69.6 & $41^{\circ} 31^{\prime} 45^{\prime \prime}$ & $72^{\circ} 51^{\prime} 50^{\prime \prime}$ & $1974-98$ & 8 \\
\hline 18 & 01196500 & Quinnipiac River at Wallingford, Conn. & 01100004 & 115 & $41^{\circ} 26^{\prime} 58^{\prime \prime}$ & $72^{\circ} 50^{\prime} 29^{\prime \prime}$ & $1968-98$ & 8 \\
\hline 19 & 01196530 & Quinnipiac River at North Haven, Conn.* & 01100004 & 128 & $41^{\circ} 23^{\prime} 24^{\prime \prime}$ & $72^{\circ} 52^{\prime} 19^{\prime \prime}$ & $1974-98$ & 8 \\
\hline 20 & 01198125 & Housatonic River near Ashley Falls, Mass. & 01100007 & 465 & $42^{\circ} 04^{\prime} 29^{\prime \prime}$ & $73^{\circ} 20^{\prime} 02^{\prime \prime}$ & $1992-98$ & 8 \\
\hline 21 & 01200600 & Housatonic River near New Milford, Conn. & 01100005 & 1,022 & $41^{\circ} 35^{\prime} 35^{\prime \prime}$ & $73^{\circ} 27^{\prime} 00^{\prime \prime}$ & 1974-98 & 4 \\
\hline
\end{tabular}


Table 1. Water-quality monitoring stations in Connecticut selected for trend analysis, 1989-98-Continued

$[*$, tidal nonsaline]

\begin{tabular}{|c|c|c|c|c|c|c|c|c|}
\hline $\begin{array}{l}\text { Map } \\
\text { reference } \\
\text { number } \\
\text { (shown on } \\
\text { fig. 1) }\end{array}$ & $\begin{array}{l}\text { Station } \\
\text { number }\end{array}$ & Station name and location & $\begin{array}{l}\text { Hydrologic } \\
\text { unit code }\end{array}$ & $\begin{array}{c}\text { Drainage } \\
\text { area } \\
\text { (square } \\
\text { miles) }\end{array}$ & Latitude & Longitude & $\begin{array}{l}\text { Period of } \\
\text { record } \\
\text { (water } \\
\text { years) }\end{array}$ & $\begin{array}{l}\text { Sampling } \\
\text { frequency } \\
\text { (number of } \\
\text { samples per } \\
\text { year used in } \\
\text { the analysis) }\end{array}$ \\
\hline 22 & 01201487 & Still River at Brookfield Center, Conn. & 01100005 & 60.6 & $41^{\circ} 2301^{\prime \prime}$ & $73^{\circ} 23^{\prime} 47^{\prime \prime}$ & $\begin{array}{l}\text { 1974-91; } \\
1993-98\end{array}$ & 8 \\
\hline 23 & 01203000 & Shepaug River near Roxbury, Conn. & 01100005 & 132 & $41^{\circ} 32^{\prime} 59^{\prime \prime}$ & $73^{\circ} 19^{\prime} 49^{\prime \prime}$ & 1974-98 & 8 \\
\hline 24 & 01205500 & Housatonic River at Stevenson, Conn. & 01100005 & 1,544 & $41^{\circ} 23^{\prime} 02^{\prime \prime}$ & $73^{\circ} 10^{\prime} 05^{\prime \prime}$ & $1968-98$ & 4 \\
\hline 25 & 01208049 & Naugatuck River near Waterville, Conn. & 01100005 & 136 & $41^{\circ} 36^{\prime} 55^{\prime \prime}$ & $73^{\circ} 03^{\prime} 30^{\prime \prime}$ & $1981-98$ & 8 \\
\hline 26 & 01208500 & Naugatuck River at Beacon Falls, Conn. & 01100005 & 260 & $41^{\circ} 26^{\prime} 32^{\prime \prime}$ & $73^{\circ} 03^{\prime} 47^{\prime \prime}$ & $1974-98$ & 8 \\
\hline 27 & 01208736 & Naugatuck River at Ansonia, Conn.* & 01100005 & 309 & $41^{\circ} 19^{\prime} 50^{\prime \prime}$ & $73^{\circ} 04^{\prime} 47^{\prime \prime}$ & 1974-98 & 8 \\
\hline 28 & 01208990 & Saugatuck River near Redding, Conn. & 01100006 & 21.0 & $41^{\circ} 17^{\prime} 40^{\prime \prime}$ & $73^{\circ} 23^{\circ} 44^{\prime \prime}$ & $1968-98$ & 4 \\
\hline 29 & 01209710 & Norwalk River at Winnipauk, Conn. & 01100007 & 33.0 & $41^{\circ} 08^{\prime} 07^{\prime \prime}$ & $73^{\circ} 25^{\prime} 36^{\prime \prime}$ & $1981-98$ & 12 \\
\hline
\end{tabular}




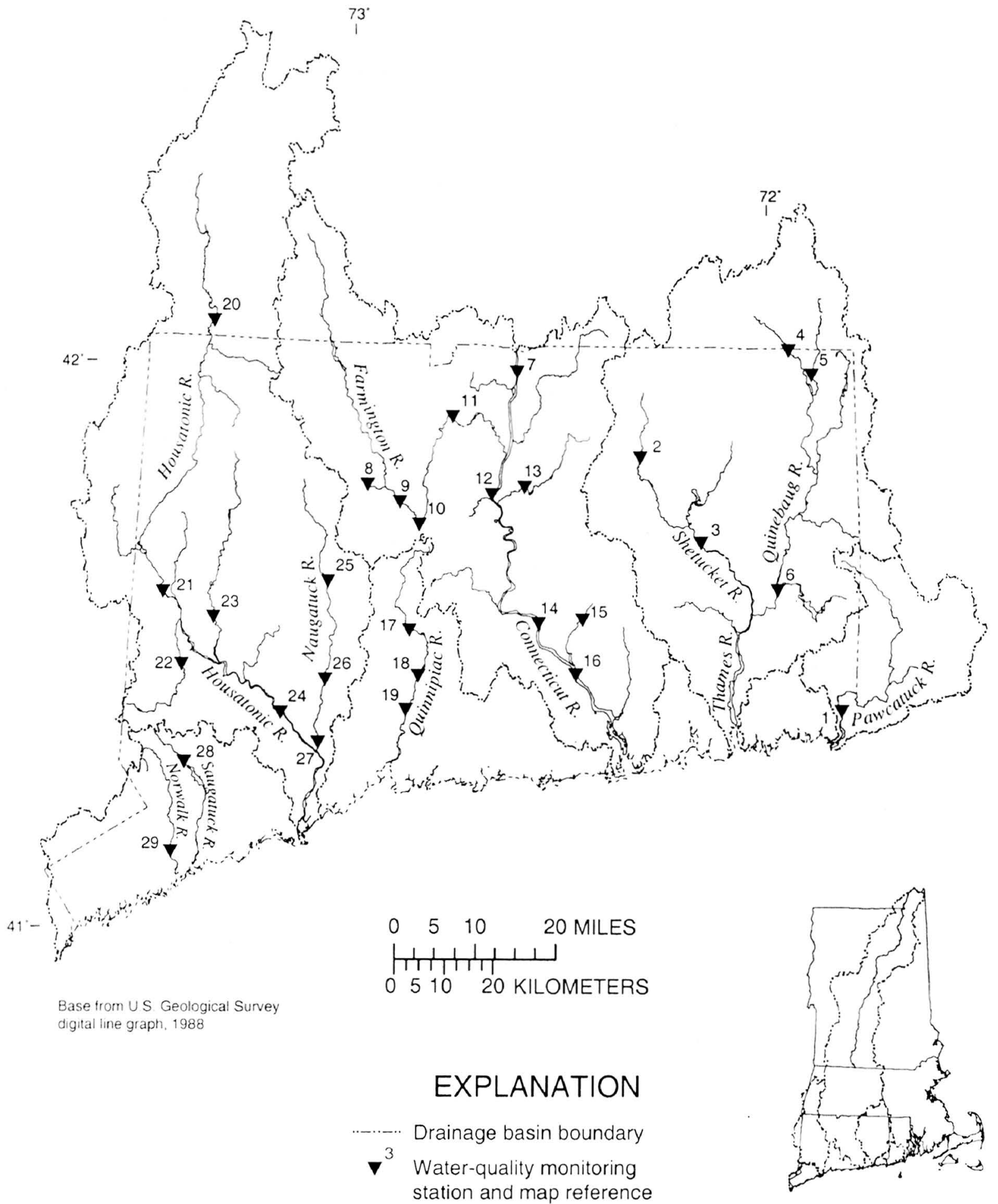
number (table 1)

Figure 1. Location of water-quality monitoring stations selected for trend analysis, 1989-98 
Table 2. Water-quality constituents and properties selected for trend analysis in Connecticut, 1989-98 [NWIS, National Water Information System; $\mu \mathrm{S} / \mathrm{cm}$, microsiemen per centimeter at 25 degrees Celsius; mg/L, milligram per liter; $\mu \mathrm{g} / \mathrm{L}$, microgram per liter; $\mathrm{mL}$, milliliter; $\%$, percent; ${ }^{\circ} \mathrm{C}$, degree Celsius; $(\mathrm{C})$, censored constituent; NTU, nephelometric turbidity units]

\begin{tabular}{|c|c|c|}
\hline Water-quality constituent or property & Units & $\begin{array}{c}\text { NWIS } \\
\text { parameter code }\end{array}$ \\
\hline \multicolumn{3}{|c|}{ PHYSICAL PROPERTIES } \\
\hline Specific conductance & $\mu \mathrm{S} / \mathrm{cm}$ & 00095 \\
\hline Turbidity & NTU & 00076 \\
\hline \multicolumn{3}{|c|}{ MAJOR CHEMICAL CONSTITUENTS AND RELATED PROPERTIES } \\
\hline Oxygen, dissolved & $\mathrm{mg} / \mathrm{L}$ & 00300 \\
\hline Oxygen, dissolved & \% of saturation & 00301 \\
\hline $\mathrm{pH}$ & standard units & 00400 \\
\hline Alkalinity. dissolved & $\mathrm{mg} / \mathrm{L}$ & 39086 \\
\hline Chloride, dissolved & $\mathrm{mg} / \mathrm{L}$ & 00940 \\
\hline Sulfate, dissolved & $\mathrm{mg} / \mathrm{L}$ & 00945 \\
\hline Silica, dissolved & $\mathrm{mg} / \mathrm{L}$ & 00955 \\
\hline Solids, residue on evaporation at $180^{\circ} \mathrm{C}$, dissolved & $\mathrm{mg} / \mathrm{L}$ & 70300 \\
\hline \multicolumn{3}{|c|}{ NITROGEN, PHOSPHORUS, AND CARBON } \\
\hline Nitrogen, lotal & $\mathrm{mg} / \mathrm{L}$ & 00600 \\
\hline Nitrogen, organic, total, as $\mathrm{N}$ & $\mathrm{mg} / \mathrm{L}$ & 00605 \\
\hline Nitrogen, ammonia-plus-organic, as $\mathrm{N}$ (Kjeldahl nitrogen) & $\mathrm{mg} / \mathrm{L}$ & 00625 \\
\hline Nitrogen, nitrite-plus-nitrate, dissolved, as $\mathrm{N}$ & $\mathrm{mg} / \mathrm{L}$ & 00631 \\
\hline Nitrogen, ammonia, dissolved, as $\mathrm{N}$ & $\mathrm{mg} / \mathrm{L}$ & 00608 \\
\hline Phosphorus, total & $\mathrm{mg} / \mathrm{L}$ & 00665 \\
\hline Carbon, organic, total & $\mathrm{mg} / \mathrm{L}$ & 00680 \\
\hline \multicolumn{3}{|c|}{ TRACE METALS } \\
\hline Aluminum, dissolved & $\mu \mathrm{g} / \mathrm{L}$ & 01106 \\
\hline Copper, dissolved & $\mu \mathrm{g} / \mathrm{L}$ & 01040 \\
\hline Lead, dissolved (C) & $\mu \mathrm{g} / \mathrm{L}$ & 01049 \\
\hline Zinc. dissolved & $\mu g / L$ & 01090 \\
\hline \multicolumn{3}{|c|}{ BACTERIA } \\
\hline Fecal coliform bacteria & colonies/100 mL & 31616 \\
\hline Enterococcus bacteria & colonies $/ 100 \mathrm{~mL}$ & 31649 \\
\hline
\end{tabular}

Final data edits were performed after careful scrutiny of the data sets for extreme outliers (values environmentally high or low). Forms containing field notes for any suspect outliers were reviewed. Field notes may contain the necessary information to verify or disqualify a particular value based on extreme or unusual field conditions, such as an unusual weather event, modified sampling methods, or known anthropogenic disturbance.

\section{Quality-Control Data}

The data set used for this study is associated with two types of quality-control (QC) data. The first type of QC data are generated with field QC samples, which consist of blanks and replicates. Blank samples are generated using a water solution that is free of the constituent of interest. Any measured value in the blank sample that was absent in the blank solution is believed to be due to contamination. Replicate samples are collected in a manner such that the samples are thought to be identical in composition. Blank and replicate samples help define any bias and variability introduced throughout sample collection, processing, shipping, and storage. Bias is the systematic error inherent in a method or measurement system. Variability is the random error in independent measurements from the result of repeated application of the process under specific conditions. Summaries of QC data compiled for the study period have been examined 
for substantial bias and variability during the study period, and no bias or variability was noted for any constituents.

The second type of QC data is generated by the USGS National Water Quality Laboratory (NWQL) to monitor any bias and variability introduced during the laboratory analysis of the samples, and consists of blanks, blind samples, and replicates. Alexander and others (1993) have suggested that water-quality trends be corrected for laboratory measurement bias and that trends in laboratory bias can be present even when data fall within control limits. Consequently, long-term, reliable QC data are necessary to determine the cause of nonenvironmental trends. Methods for correcting water-quality trends for measurement bias require further research and have yet to be used routinely. Summaries of QC data compiled by the NWQL have been examined for substantial biases during the study period, and these biases are discussed for affected constituents.

\section{Effects of Method Changes on Water-Quality Data}

Methods of sample collection, processing, and laboratory analysis have changed during the study period. Changes in laboratory methods have created multiple detection limits for several constituents. These changes and the known effects on water-quality data have been defined by corresponding QC data generated in the laboratory.

Water-quality samples were collected, processed, and analyzed according to USGS protocols described by Guy and Norman (1970), Goerlitz and Brown (1972), Greeson and others (1977), Skougstad and others (1979), Friedman and Erdmann (1982), Wershaw and others (1987), Edwards and Glysson (1988), and Fishman and Friedman (1989). The methods for the collection, processing, and analysis of water-quality samples have undergone several changes during the period of this study (see series of USGS Office of Water Quality and NWQL Technical Memoranda accessed on 12/12/00 at URLs http://water. usgs.gov/admin/memo/QW/auto.html and http://wwwnwql.cr.usgs.gov/Public/nwql_memo.html). Changes in laboratory methods and technology may complicate the detection of true environmental trends or may create apparent trends that do not represent ambient water-quality conditions (Schertz and others, 1991). Some method changes that may affect trend analysis and interpretation are presented here. The effects of changes in laboratory analysis methods on historical nutrient data also were discussed by Trench (1999), Trench (1996), and Zimmerman and others (1996).

Chloride and sulfate concentrations reported during the early 1990s show a positive bias (Alexander and others, 1993). NWQL results of chloride concentration from the ion chromatography method used from April 1990 through October 20,1992, resulted in standard reference water sample values with a positive bias of less than one standard deviation (U.S. Geological Survey NWQL Technical Memorandum No. 93.03, 1992; C.J. Patton and others, U.S. Geological Survey, written commun., 1992). The positive bias could create the appearance of a false positive trend or mask a true environmental trend. The magnitude of any positive trends should be considered in light of this potential bias. Furthermore, the positive bias may have diminished some negative trends that otherwise could have been considered significant decreases.

Sulfate values reported from the NWQL from April 1990 through March 31, 1992 showed a positive. bias on the order of 0.5 to $3 \mathrm{mg} / \mathrm{L}$ for samples with concentrations of 15 to $75 \mathrm{mg} / \mathrm{L}$ (Alexander and others, 1996). The positive bias introduced during laboratory analysis could mask a downward trend. In this study, however, the sulfate concentration trend slopes are all downward ( -0.15 to $-1.2 \mathrm{mg} / \mathrm{L} /$ year $)$, so any bias correction would only change the magnitude, not the direction of the trend.

A previous method used to analyze for Kjeldahl nitrogen was found to affect low-level concentrations of this constituent, and consequently calculations of total nitrogen concentrations as well (Patton and Gilroy, 1999). The changes in laboratory analysis methods affected concentrations of Kjeldahl nitrogen; these effects were identified in water year 1992 based on tests by the Office of Water Quality Blind Sample Program. The difference between the two methods for the median concentration of nitrogen was about $0.1 \mathrm{mg} / \mathrm{L}$ (Patton and Truitt, 2000). The difference represents a decrease in Kjeldahl nitrogen concentration that could be interpreted as a false environmental trend. Therefore, for this study, data for nitrogen constituents analyzed using the Kjeldahl digestion method have been edited to include only water years 1992-98.

Phosphorus data analyzed prior to a May 1, 1990 method change have a negative bias, as reported by the 
NWQL. The method used from May 1, 1990, to September 30, 1991 also produced a negative bias in the reported data set (U.S. Geological Survey Office of Water Quality Technical Memorandum No. 92.10, 1992; D.A. Rickert, U.S. Geological Survey, written commun., 1992). This negative bias could result in false upward trends for sets of water-quality data that cross this time boundary. Although the negative bias has been documented, the results leave uncertainty as to how the bias has affected the values in specific rivers (Zimmerman and others, 1996, p. 29-30). For this reason, the trend results from this study could be analyzed further on a site-by-site basis for rivers with low reported total phosphorus concentrations that are more likely to have been affected by the analytical method bias. In addition to the negative bias, a minimum detection limit change from less than $0.01 \mathrm{mg} / \mathrm{L}$ to less than $0.05 \mathrm{mg} / \mathrm{L}$ has been recommended for phosphorus data reported since 1991 due to analytical method limitations (U.S. Geological Survey NWQL Technical Memorandum No. 98.07, 1998), and this change was applied to the data sets in this study. Use of the greater detection limit results in a loss of low-level phosphorus concentration data, which may mask trends.

The USGS NWQL began using the new Inductively Coupled Plasma/Mass Spectrometry (ICP/MS) analysis method for low-level inorganic analysis (trace metals) in water year 1994. Also, beginning in water year 1994, the USGS began using a new protocol for collecting and processing surface-water samples for low-level inorganic analysis (trace metals), with results in the microgram-per-liter or part-per-billion range (U.S. Geological Survey Office of Water Quality Technical Memorandum No. 94.09, 1994). Previous collection and processing methods were adequate for analyses in the milligram-per-liter or part-per-million range. As an example, the result of method changes are shown in a plot showing the concentration of dissolved zinc as a function of time for station 01124000 (Quinebaug River at Quinebaug) (fig. 2). The plot indicates a trend that coincides with the changes in protocol in water year 1994. Analysis of trends in trace metal concentrations across the date of protocol change is invalid for stations with most data values at or near the detection limits. Stations with most concentration values below the detection limit for the entire study period are not affected by the method change. Trends in trace metals are unlikely to be detected in clean streams with highly censored (more than 50 percent) data sets. Trace metal trends for 11 stations were analyzed for the 5 -year period after the protocol change (water years 1994-98). The stations were chosen to represent different land uses, geologic settings, and major drainage basins.

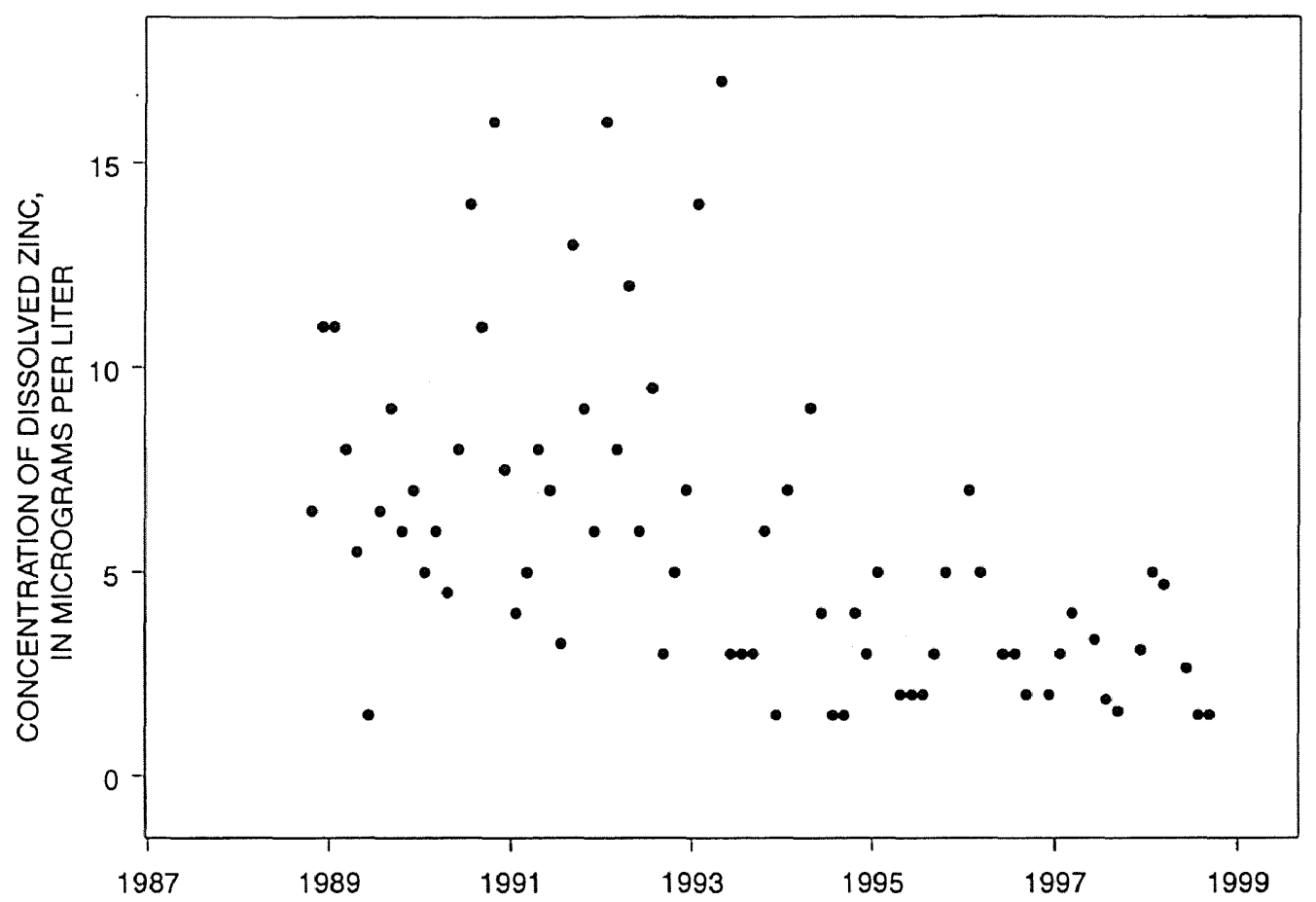

Figure 2. Effects of changes in methods for sample collection, processing, and analysis for dissolved zinc, Quinebaug River at Quinebaug, Conn., 1989-98. 
The analysis of trace metal data is further complicated by several changes in the minimum reporting limit for individual metal constituents. On April 1, 1996, the reporting limit for lead was lowered from 100 to $10 \mu \mathrm{g} / \mathrm{L}$, and the reporting limit for zinc was lowered from 10 to $3 \mu \mathrm{g} / \mathrm{L}$. Reassessment by the NWQL of the sensitivity of the analysis and further blank sample results caused further changes in the reporting limits for aluminum ( 5 to $10 \mu \mathrm{g} / \mathrm{L}$ ), lead ( 10 to $100 \mu \mathrm{g} / \mathrm{L}$ ), zinc ( 3 to $20 \mu \mathrm{g} / \mathrm{L}$ ), and silica (0.01 to $0.1 \mathrm{mg} / \mathrm{L}$ ) on December 22, 1997. Assistance on the interpretation and use of historical data prior to December 22, 1997 can be found in U.S. Geological Survey NWQL Technical Memorandum No. 98.07.

\section{Seasonal Kendall Test for Trend Analysis}

The seasonal Kendall test is a variation of the Mann-Kendall test, which tests the hypothesis that the sum of the signs of all differences between successive data is significantly different from zero (Hirsch and others, 1982; Smith and others, 1982). The seasonal Kendall test uses the same hypothesis, but it limits data comparisons to those of similar seasons to reduce the effect that seasonal differences in concentration may have on trend detection. The Mann-Kendall test statistic for each season is subsequently summed for an overall seasonal Kendall test statistic. The total variance of the seasonal Kendall test statistic is the sum of the seasonal variation. The statistical significance is obtained from the normal distribution and reported for the standardized seasonal Kendall test statistic (Helsel and Hirsch, 1992). This effort minimizes seasonal differences to describe water-quality trends across several years.

The seasonal Kendall test statistic is used to determine the presence or absence of a monotonic (steadily upward or downward) trend. In this report, an attained statistical significance level, or p-value, for a constituent of less than or equal to 0.05 has been selected to indicate the presence of a significant trend. The $\mathrm{p}$-value is the probability that a detected trend resulted from a chance arrangement of the data rather than from an actual change in concentration. The smaller the p-value, the more significant the trend. The $\mathrm{p}$-value attained can be affected by serial correlation for periods of record that exceed 10 years. Generally, the seasonal Kendall test is robust until the serial correlation coefficient reaches about 0.20 . Adjustment of the $\mathrm{p}$-value was not necessary for this study.
In addition to significance and direction of trend, trend slope (units per year) for all seasonal comparisons for the 10 -year period is reported. A trend may be approximately monotonic over a long period of time, may change abruptly as in a step trend, or may vary in direction and slope over time. The slope of a trend is an approximation to actual, temporal variations because the actual data may change linearly, by steps, or even contain reversals in direction during the 10 -year period. The abrupt changes, or step trends, may be analyzed using different time intervals for trend detection or graphically visualized using a plot of concentration as a function of time. Although step trends can be useful indicators of possible sudden changes in wastewatertreatment practices or land use, the results of monotonic trend procedures are better suited for comparison and summary of numerous stations and constituents in a statewide or regional analysis (Schertz and others, 1991). Therefore, the reported trend slope for this study is a measure of the monotonic trend throughout the 10-year period, even though slope and direction of trend may have changed within the period.

The seasonal Kendall analysis was done using methods developed by Smith and others (1982) and Helsel and Hirsch (1992). This analysis requires data to have been collected at a constant frequency throughout the study period. A reduction in sampling at some stations for selected years resulted in data that were not at a constant frequency, so for this study, the median of multiple values in a season was used to achieve a uniform frequency. Although this may introduce bias towards years with more frequent data collection, the results in this study are not biased because only two stations had a reduction in samples for 2 of the 10 years of record. For most stations and constituents, eight seasons were used.

Water-quality data are reported at levels above the analytical limitations or detection limit. Some samples have data values below this limit and are stored in the database with "less-than" coded values. Upon retrieval, these less-than values, commonly referred to as censored values, are edited to one-half the detection limit (Helsel and Hirsch, 1992). The nonparametric seasonal Kendall test is based on a rank-sum analysis in which the censored values are assigned ranks that are tied for all values below the detection limit. Therefore, the censored values affect the accuracy of the trend slope but not the direction. Use of the seasonal Kendall test on data with more than 5 percent of the values below a detection limit may bias trend 
slope approximation (Helsel and Hirsch, 1992). For this reason, the trend slope was not reported in this study for constituents for which more than 5 percent of the data values are censored.

Changes in laboratory analytical methods resulted in multiple detection limits for several constituents. Where multiple censoring levels were present, the highest detection limit was used. For this study, censored values for each constituent with multiple detection limits were set to one-half the highest detection limit for that constituent. The assignment to onehalf the highest detection limit enables the analysis of trends using a conservative estimate for all constituents affected by multiple detection limits; this affects the slope and not the direction of the trend.

Further analysis of highly censored data could be done using the Tobit test (Schertz and others, 1991). That test was not applied in this study, however, where most of the censored data was for trace metals. Highly censored trace-metal data indicate a clean stream with very low concentrations of trace metals. Consequently, the need for further investigation for a trend is minimal. In the more degraded streams, sufficient data above the detection limit were available, and the seasonal Kendall test was applied.

Changes in discharge may have a more substantial effect on trends in water quality than land use or other anthropogenic factors. Flow adjustment reduces the flow-related variability in water quality and increases the chance of detecting trends due to factors other than discharge. Flow-adjusted concentration trends can be examined to relate causal factors in a basin to water quality. Conversely, ambient concentration trends can be examined for comparisons with water-quality criteria or habitat criteria standards.

\section{Analysis of Concentration Trends}

Data for 22 constituents (table 2 ) at 29 stations (table 1; fig. 1) were analyzed for trends in concentration. Water-quality samples were collected at the 29 stations for all or parts of water years 1989-98. These stations represent all major drainage basins in the State (fig. 1) - 5 stations in the Thames River Basin, 10 in the Connecticut River Basin, 8 in the Housatonic River Basin, and 6 in basins that drain coastal areas.

Data were retrieved from the USGS waterquality database (QWDATA). Each data set was reviewed using a combination of data tables, summary statistics, and graphical methods. After careful examination of the data sets, the period of record used for trend analysis was determined based on missing record, censored data, and historical analytical bias. The period of record for analysis (table 3, column 3) was selected to best represent true environmental values for the each constituent.

Trends were analyzed for each station-constituent pair (appendixes 1,2 ). The results indicate the presence of a trend, the direction of the trend, and the trend slope. The direction of the trend is indicated by the arithmetic sign of the slope. The trend slope is the linear slope of the monotonic trend, in the same units as the constituent values.

\section{Analysis of Flow-Adjusted Trends}

Surface-water discharge may obscure the trend in the constituent of interest if the constituent is strongly correlated with discharge. In these cases, it is necessary to remove the effects of discharge to see how the flow-adjusted concentration of the constituent is changing with time. Of the 29 stations selected for this study, 24 stations have either continuous or instantaneous discharge data available. Five stations are tidally affected and do not have discharge data available (table 1). Of the 24 stations, nine were selected that have the network's most complete long-term continuous surface-water discharge data, and flow-adjustment techniques were applied to data sets for selected constituents at these stations.

The nine water-quality stations selected for application of flow-adjustment procedures represent different drainage basins, land uses, and population densities in Connecticut. Five constituents (turbidity, chloride, total nitrogen, dissolved nitrite plus nitrate, and total phosphorus) were chosen for flow adjustment based on exploratory data analysis of the relation between concentration and discharge for all stations and constituents.

Several procedures can be used to adjust concentrations for flow. All procedures involve the use of a best-fit equation to model the concentration-discharge relation. Several models have been identified as providing a good fit for many constituents being analyzed for trend (Schertz, 1990). The LOWESS procedure was chosen to minimize the effect of outliers in fitting a smooth line to data. The LOWESS procedure consists of using distance and residual weighting 
functions with weighted least squares (Cleveland, 1979). A predicted (smoothed) value is obtained for each observation. Large residuals at greater distance from the observation are assigned smaller weights. A fraction of the total observations, called the $f$-value, is used in the LOWESS procedure. Values between 0.3 and 0.7 provide a fit to the data without abrupt changes in local slope. Lanfear and Alexander (1990) suggest an $f$-value of 0.5 , based on review of numerous water-quality discharge plots of data from USGS stations. Consequently, an f-value of 0.5 was selected for the LOWESS-smoothing procedures used in this analysis. Each station-constituent pair was modeled using the LOWESS smooth, a curve-fitting graphical analysis in S-Plus 2000 statistical software (Insightful Corp., 1999).

A total of 45 station-constituent pairs were modeled-5 constituents at each of the 9 stations. The LOWESS smooth function was modeled to the concentration-discharge relation. A concentration-discharge model was used for dissolved water-quality constituents, such as chloride, that are typically not sorbed to particles. A log-concentration/log-discharge model was used for constituents that are typically non-conservative in transport (turbidity, total nitrogen, dissolved nitrite plus nitrate, and phosphorus). For comparison of trend results among stations, the mixture of normal and log-transformed concentrations should be avoided to eliminate the difficulty of comparing normal and logtransformed estimates of the trend slopes.

The residuals from the LOWESS procedure were plotted and analyzed for homoscedasticity (constant variance) and approximate normality. The seasonal Kendall test then was used to detect trends in the residuals. In this procedure, trend slope is not meaningful because the residuals are used, rather than values in the same units as the constituent values. All previous assumptions for the seasonal Kendall test were observed in the analysis of the residuals. As in the case of concentration trends, a trend was considered significant when the $\mathrm{p}$-value was less than or equal to 0.05 .

\section{Analysis of Instantaneous Stream Discharge Trends}

Of the 29 stations selected for this study, five stations are tidally affected and do not have discharge data available. The remaining 24 stations were analyzed for trend in stream discharge using the same procedures described for analysis of concentration trends.

\section{TRENDS IN SURFACE WATER QUALITY IN CONNECTICUT, 1989-98}

Statistically significant water-quality trends have been summarized for 22 constituents and 29 stations during the 10-year period (table 3). Total number of stations with trends, listed for each constituent, include both flow-adjusted and unadjusted trends. Information that is useful to interpret the importance of trends includes the direction of the trend, the statistical significance of the trend, and the trend slope. The results from the individual trend tests, the statistical significance of the trend, and the trend slope for unadjusted concentration trends are shown in appendixes 1 and 2 . Results for flow-adjusted trends are shown in appendix 3.

Very small changes in water quality may represent statistically significant trends and may be important if they are geographically widespread or represent persistent environmental changes. Interpretation of the trend slope is valuable to assess constituent trends and their relation to local water-quality standards and goals. A small trend slope may be statistically significant but not environmentally important in terms of local waterquality standards. Interpretation of significant waterquality trends by water-resource managers can include evaluation of the trend slopes and the mean waterquality concentrations in comparison with waterquality standards.

Results of unadjusted trend analysis are shown in figures 3-25. Concentration and flow-adjusted trend results are shown at station locations as an up triangle (upward trend), down triangle (downward trend), circle (no trend), or " $x$ " (insufficient data for trend analysis). Flow-adjusted trend results for turbidity, dissolved chloride, total nitrogen, dissolved nitrite-plus-nitrate, and total phosphorus at nine stations are shown in figures 26-30. No significant trends in stream discharge were found at the 24 stations with discharge record. 
Table 3. Statewide summary of statistically significant trends in water quality at selected stations in Connecticut, water years $1989-98$

[Trend slopes are not reported for censored constituents. Median trend slope is the median of trend slopes at all stations. Trends summarized have an attained significance level of less than or equal to 0.05 . See appendixes for trend results for individual stations. (C), censored constituent; \%, percent; ${ }^{\circ}$, degrees; --, not applicable]

\begin{tabular}{|c|c|c|c|c|c|c|c|}
\hline \multirow[b]{3}{*}{ Water-quality constituent or property } & \multirow{3}{*}{$\begin{array}{l}\text { Number of } \\
\text { stations }\end{array}$} & \multirow{3}{*}{$\begin{array}{l}\text { Period of } \\
\text { record used } \\
\text { for analysis }\end{array}$} & \multicolumn{4}{|c|}{ Total significant trends } & \multirow{3}{*}{$\begin{array}{l}\text { No trend } \\
\text { (number of } \\
\text { stations) }\end{array}$} \\
\hline & & & \multicolumn{2}{|c|}{ Upward } & \multicolumn{2}{|c|}{ Downward } & \\
\hline & & & $\begin{array}{l}\text { Number of } \\
\text { stations }\end{array}$ & $\begin{array}{c}\text { Median } \\
\text { trend slope } \\
\text { (units/year) }\end{array}$ & $\begin{array}{l}\text { Number of } \\
\text { stations }\end{array}$ & $\begin{array}{c}\text { Median } \\
\text { trend slope } \\
\text { (units/year) }\end{array}$ & \\
\hline \multicolumn{8}{|c|}{ PHYSICAL PROPERTIES } \\
\hline Specific conductance & 29 & $1989-98$ & 4 & 3.8 & 0 & -- & 25 \\
\hline Turbidity & 28 & 1989-98 & 5 & 0.07 & 0 & - & 23 \\
\hline \multicolumn{8}{|c|}{ MAJOR CHEMICAL CONSTITUENTS AND RELATED PROPERTIES } \\
\hline Oxygen, dissolved & 29 & $1989-98$ & 1 & 0.28 & 4 & -0.10 & 24 \\
\hline Oxygen, dissolved, as percent saturation & 29 & 1989-98 & 4 & 0.78 & 1 & -0.67 & 24 \\
\hline $\mathrm{pH}$ & 29 & $1989-98$ & 3 & 0.02 & 2 & -0.06 & 24 \\
\hline Alkalinity, dissolved, as $\mathrm{CaCO}_{3}$ & 29 & $1992-98$ & 0 & -- & 10 & -1.2 & 19 \\
\hline Chloride, dissolved, as $\mathrm{Cl}$ & 28 & $1989-98$ & 9 & 0.50 & 0 & -.. & 19 \\
\hline Sulfate, dissolved, as $\mathrm{SO}_{4}$ & 28 & $1989-98$ & 0 & -- & 23 & -0.32 & 5 \\
\hline Silica, dissolved, as $\mathrm{SiO}_{2}$ & 11 & $1989-98$ & 0 & -. & 0 & -- & 11 \\
\hline Solids, dissolved at $180^{\circ} \mathrm{C}$ & 28 & $1989-98$ & 6 & 1.2 & 0 & -- & 22 \\
\hline \multicolumn{8}{|c|}{ NITROGEN, PHOSPHORUS, AND CARBON } \\
\hline Nitrogen, total, as $\mathrm{N}$ & 29 & $1992-98$ & 2 & 5.9 & 1 & -6.9 & 26 \\
\hline Nitrogen, organic, total, as $\mathrm{N}$ & 23 & $1992-98$ & 0 & .. & 2 & -7.8 & 21 \\
\hline Nitrogen, ammonia-plus-organic, as $N(C)$ & 28 & $1992-98$ & 0 & -- & 4 & -7.7 & 24 \\
\hline Nitrogen, nitrite-plus-nitrate, dissolved, as $\mathrm{N}$ & 8 & $1992-98$ & 0 & -- & 1 & -7.0 & 7 \\
\hline Nitrogen, ammonia, dissolved, as N (C) & 9 & $1989-98$ & 0 & -- & 4 & -0.01 & 5 \\
\hline Phosphorus, total, as $\mathrm{P}$ & 20 & $1989-98$ & 2 & 0.02 & 7 & -0.003 & 11 \\
\hline Carbon, organic, total, as C & 26 & $1989-98$ & 2 & 0.10 & 1 & -0.07 & 23 \\
\hline \multicolumn{8}{|c|}{ TRACE METALS } \\
\hline Aluminum, dissolved, as $\mathrm{Al}$ & 8 & $1994-98$ & 1 & 4.1 & 1 & -5.0 & 6 \\
\hline Copper, dissolved, as $\mathrm{Cu}$ & 5 & $1994-98$ & 0 & -- & 0 & -- & 5 \\
\hline Lead, dissolved, as $\mathrm{Pb}(\mathrm{C})$ & 0 & $1994-98$ & -. & -- & -- & -- & -- \\
\hline Zinc, dissolved, as $\mathrm{Zn}$ & 6 & $1994-98$ & 0 & -- & 2 & -1.3 & 4 \\
\hline \multicolumn{8}{|c|}{ BACTERIA } \\
\hline Fecal coliform bacteria & 28 & $1989-98$ & 5 & 72 & 0 & - & 23 \\
\hline Enterococcus bacteria & 17 & $1991-98$ & 2 & 99 & 0 & -- & 15 \\
\hline
\end{tabular}




\section{Concentration Trend Results}

\section{Physical Properties}

Data were analyzed for two physical properties, specific conductance and turbidity. Specific conductance increased in two rivers in the southeastern part of the State and in two rivers in the south-central part of the State (fig. 3). Turbidity increased at five stations scattered across the study area (fig. 4).

\section{Major Chemical Constituents and Related Properties}

Dissolved oxygen concentrations decreased at four stations and increased at one station (fig. 5). Dissolved oxygen (DO) as a percent of saturation increased at four stations and decreased at one station (fig. 6). Decreases in both concentration and percent saturation were detected for the Quinnipiac River at Wallingford (figs. 5 and 6). Values of $\mathrm{pH}$ increased at three stations (Connecticut River at Thompsonville and East Haddam, and Still River at Brookfield) and decreased at two stations (French River at North Grosvenordale and Norwalk River at Winnipauk) (fig. 7). Trends in $\mathrm{DO}$ and $\mathrm{pH}$ were scattered statewide, and most stations showed no trend.

Trends in dissolved oxygen and $\mathrm{pH}$ should be evaluated in light of the likely diurnal fluctuation in values, due to photosynthetic activity of instream algal populations. Because regular water-quality sampling is conducted during daylight hours, trend results only represent daytime conditions; other conditions may prevail during the night. Preliminary results from continuous, water-quality monitoring (15-minute values recorded during consecutive days) show wide variation between daytime and nighttime instream conditions. Several dynamic river systems throughout the State show regular diurnal fluctuations throughout the summer months (Davies and others, 1999; Ranzau and others, 2000, 2001).

Alkalinity data were analyzed for trend at 29 stations for the 1992-98 water years, because of limited field alkalinity data available at most stations for 1989-91 water years. Results indicated a decrease at 10 stations scattered statewide and no change at the other 19 stations (fig. 8).

Chloride data were analyzed at 28 stations. Nine upward trends were detected, and data for 19 stations showed no trend during the study period (fig. 9). All three Quinnipiac River stations, two Farmington River stations, two Thames River stations, the Salmon River station, and the Pawcatuck River station had upward trends in chloride.

Sulfate concentrations decreased at 23 of the 28 stations (fig. 10). The downward trend is a statewide environmental phenomenon and is consistent with other stations in the eastern United States (Mast and Turk, 1999). Reduction of sulfur dioxide emission in the Northeast United States since 1970 (Husar and others, 1991) may be the cause of the decline in sulfate concentration in streamwater.

No trends in silica concentrations were detected for the 11 stations analyzed for trend (fig. 11). The remainder of the stations had insufficient data for analysis of silica trends.

Upward trends in dissolved solids were detected for 6 of the 28 stations analyzed. All six of these stations are in the eastern half of the State, in the Thames, Pawcatuck, and Salmon River Basins (fig. 12). The results for dissolved solids differ from those for specific conductance in the eastern highlands. The difference is because the ratio of dissolved solids to specific conductance ranges from $0.55: 1$ to $0.81: 1$ (not $1: 1$ ).

\section{Nitrogen, Phosphorus, and Carbon}

Nitrogen constituents were analyzed for trends during water years 1992-98, due to the previously discussed potential lab bias for data prior to water year 1992. Total nitrogen concentration, which was analyzed at 29 stations, increased at 2 stations (Saugatuck River near Redding and Norwalk River at Winnipauk) and decreased at 1 station (Willimantic River at Merrow) (fig. 13). Total organic nitrogen concentration decreased in 2 out of 23 stations with sufficient data for trend analysis (Willimantic River at Merrow and Still River at Brookfield Center) (fig. 14). Trend analysis of ammonia-plus-organic nitrogen (Kjeldahl nitrogen) data for the 28 stations with sufficient data showed 4 downward trends (Willimantic River at Merrow, Pequabuck River at Farmington, Connecticut River at East Haddam, and Still River at Brookfield Center) (fig. 15). Concentration of dissolved nitrite-plus-nitrate nitrogen, analyzed at 
8 stations with sufficient data for trend analysis, decreased at 1 station (Shetucket River at South Windham) (fig. 16). Dissolved ammonia nitrogen data were analyzed for the 9 stations with sufficient data.

Four downward trends were detected (Shetucket River at South Windham, and Connecticut River at Thompsonville, at Middle Haddam, and at East Haddam) (fig. 17).

Concentrations of total phosphorus decreased at 7 stations statewide and increased at 2 stations (Naugatuck River at Beacon Falls and at Ansonia). No trends were detected for 11 stations; 9 stations lacked sufficient data for trend analysis (fig. 18).

Concentrations of total organic carbon increased at 2 stations (Quinebaug River at Jewett City and Quinnipiac River at North Haven) and decreased at 1 station (Salmon River near East Hampton) (fig. 19). The remaining 23 stations (of 26 analyzed) showed no significant trend.

\section{Trace Metals}

Data for four trace metals were evaluated for trend analysis at 11 stations. A high percentage of censored data reduced the number of stations analyzed for each of the four trace metals (figs. 20-23).

Dissolved aluminum was analyzed for trends at eight stations, with one upward trend detected in the Quinebaug River at Jewett City and one downward trend detected in the Quinnipiac River at Wallingford (fig. 20). Dissolved copper was analyzed for trends at five stations, and no significant trends were detected (fig. 21). Dissolved lead values were highly censored at all 11 stations; therefore, trend detection was not possible (fig. 22). Of the six stations analyzed for trends in dissolved zinc, downward trends were noted at two stations (Farmington River at Tariffville and Hockanum River at East Hartford) (fig. 23).

\section{Bacteria}

Data for fecal coliform and enterococcus bacteria were analyzed for trends (figs. 24-25). Enterococcus bacteria was added to the sampling schedule in water year 1991 and evaluated for the period of record from water year 1991-98. Upward trends in fecal coliform bacteria were detected at 5 of 28 stations evaluated, and upward trends in enterococcus bacteria were detected at 2 of 17 stations. Increases in bacteria were detected in the Shetucket, Quinebaug, Naugatuck, and Quinnipiac Rivers. The shorter period of record for a station or constituent may hamper the detection of trends. If a slight increase or decrease has taken place, it takes a longer period of record for the significance to become evident.

\section{Flow-Adjusted Trend Results}

\section{Physical Properties}

Flow-adjusted turbidity data were analyzed at 9 stations. Results indicated no trend in turbidity for 8 stations and an increase at 1 station, Shetucket River at South Windham (fig. 26).

\section{Chemical Constituents}

Flow-adjusted chloride concentrations were analyzed at 9 stations. Upward trends were detected at 4 stations (Quinnipiac River at Wallingford, Farmington River at Tariffville, Quinebaug River at Jewett City, and Shetucket River at South Windham), and data for 5 stations showed no trend during the study period (fig. 27).

\section{Nitrogen and Phosphorus}

Flow-adjusted concentrations of both total nitrogen and dissolved nitrite-plus-nitrate nitrogen were analyzed for trends during water years 1992-98, due to the previously discussed potential lab bias for data prior to the water year 1992 . Total nitrogen, analyzed at nine stations, showed no trends (fig. 28). Dissolved nitrite-plus-nitrate nitrogen, analyzed at nine stations with sufficient data for trend analysis, decreased at one station (Shetucket River at South Windham) and increased at one station (Naugatuck River at Beacon Falls) (fig. 29).

Flow-adjusted concentration of total phosphorus decreased at two stations (Shetucket River at South Windham and Farmington River at Tariffille). No trends were detected for three stations; the remaining four stations lacked sufficient data for trend analysis (fig. 30). 


\section{Comparison of Trend Results}

The most prevalent trends during 1989-98 are summarized (table 4) for comparison with trends detected in an earlier study period of 1975-88 (Trench, 1996). Values of specific conductance and concentrations of chloride and dissolved solids continued to trend upward during the current study period. Differences can be noted in results for turbidity and fecal coliform bacteria, both of which had downward trends during the 1975-88 period, and upward trends during the 1989-98 period. In contrast to upward nitrogen trends statewide for the 1975-88 study, no current statewide trends were found for the nitrogen constituents during the 1992-98 period. Downward trends in phosphorus were detected in both the 1975-88 and 1989-98 study periods. Upward trends in sulfate were detected during 1975-82; however, downward trends were widespread during 1989-98. The geographic areas where trends were identified during the two study periods differed for some constituents, and this should be noted when making any specific comparisons.

Table 4. Summary of the most prevalent concentration trends in water quality in Connecticut, water years 1975-88 and 1989-98

\begin{tabular}{|c|c|c|c|c|}
\hline \multirow{2}{*}{ Property or constituent } & \multicolumn{2}{|r|}{$1975-88$} & \multicolumn{2}{|r|}{$1989-98$} \\
\hline & Direction & Areas & Direction & Areas \\
\hline Specific conductance & Upward & $\begin{array}{l}\text { Central lowland, } \\
\text { western uplands }\end{array}$ & Upward & $\begin{array}{c}\text { Statewide (except } \\
\text { southwestern areas \& } \\
\text { western uplands) }\end{array}$ \\
\hline Turbidity ${ }^{\prime}$ & Downward & Statewide & Upward & $\begin{array}{l}\text { Statewide (except } \\
\text { southwestern areas) }\end{array}$ \\
\hline Chloride & Upward & Statewide & Upward & $\begin{array}{c}\text { Statewide (except } \\
\text { southwestern areas \& } \\
\text { western uplands) }\end{array}$ \\
\hline Sulfate ${ }^{2}$ & Upward & Eastern and western uplands & Downward & Statewide \\
\hline Dissolved solids & Upward & $\begin{array}{l}\text { Primarily central lowland, west- } \\
\text { ern uplands }\end{array}$ & Upward & Primarily eastern uplands \\
\hline Total nitrogen ${ }^{3}$ & Upward & Statewide & Upward & Southwestern areas \\
\hline Total organic nitrogen & Upward & Statewide & No trend & Statewide \\
\hline Total phosphorus & Downward & $\begin{array}{c}\text { Statewide (except } \\
\text { Farmington River Basin) }\end{array}$ & Downward & $\begin{array}{c}\text { Scattered statewide } \\
\text { (except Naugatuck River Basin) }\end{array}$ \\
\hline Fecal coliform bacteria & Downward & Scattered statewide & Upward & $\begin{array}{c}\text { Eastern uplands, } \\
\text { Quinnipiac River and Naugatuck } \\
\text { River }\end{array}$ \\
\hline
\end{tabular}

\footnotetext{
${ }^{1}$ Period of record for turbidity in earlier study was 1978-88.

${ }^{2}$ Period of record for sulfate in earlier study was 1975-82.

${ }^{3}$ Period of record for total nitrogen and total organic nitrogen in current study was 1992-98.
} 

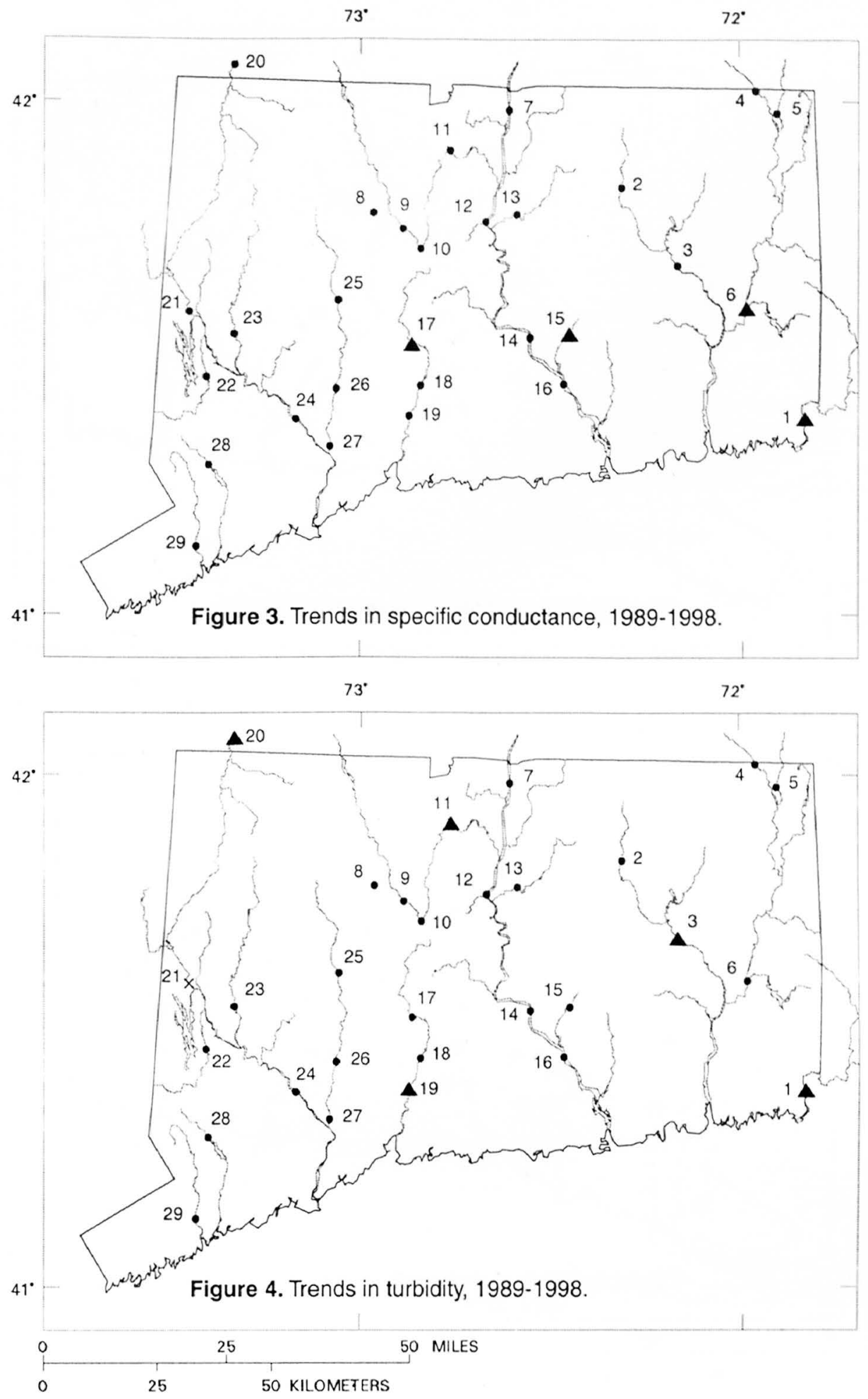

\section{EXPLANATION}

- Upward trend

$\nabla$ Downward trend

- No significant trend

$\times$ Insufficient data for trend analysis 

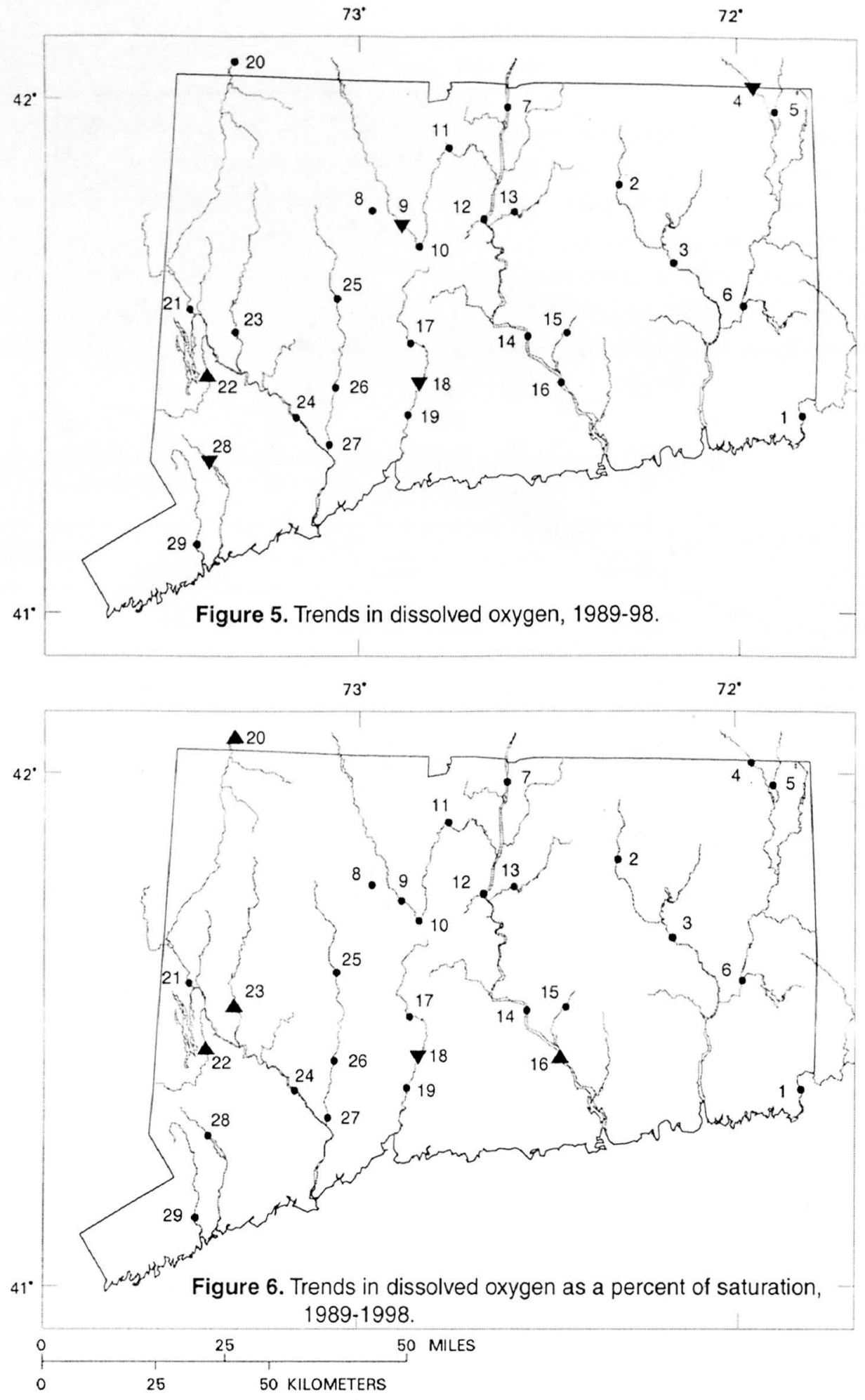

EXPLANATION

- Upward trend

จ Downward trend

- No significant trend

$x$ Insufficient data for trend analysis 

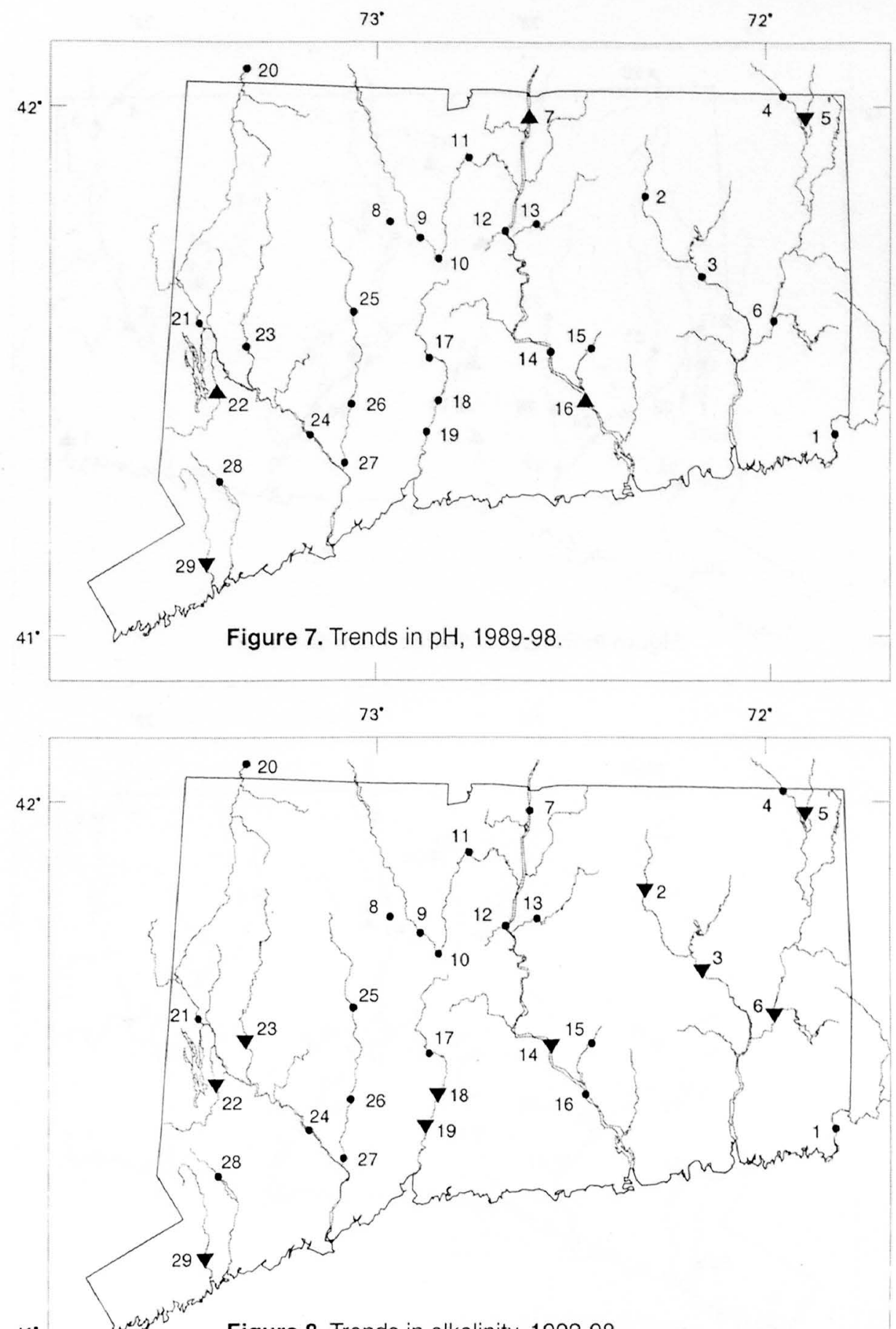

41. Wrape Figure 8. Trends in alkalinity, 1992-98.

$\begin{array}{lll}0 & 25 & 50 \\ 0 & 25 & 50 \text { KILOMETERS }\end{array}$

\section{EXPLANATION}

- Upward trend

$\nabla$ Downward trend

- No significant trend

$x$ Insufficient data for trend analysis 

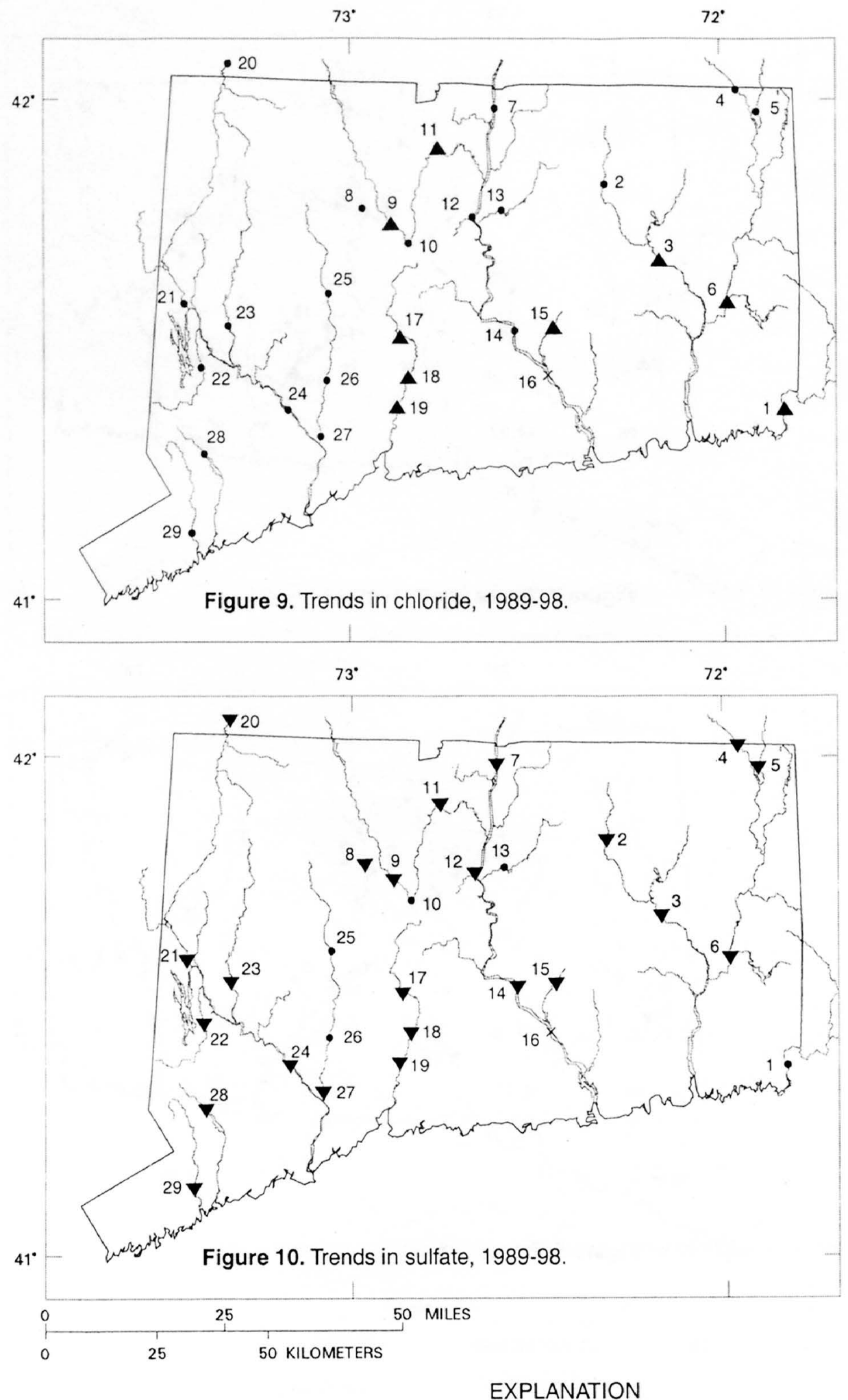

- Upward trend

$\nabla$ Downward trend

- No significant trend

$\times$ Insufficient data for trend analysis 

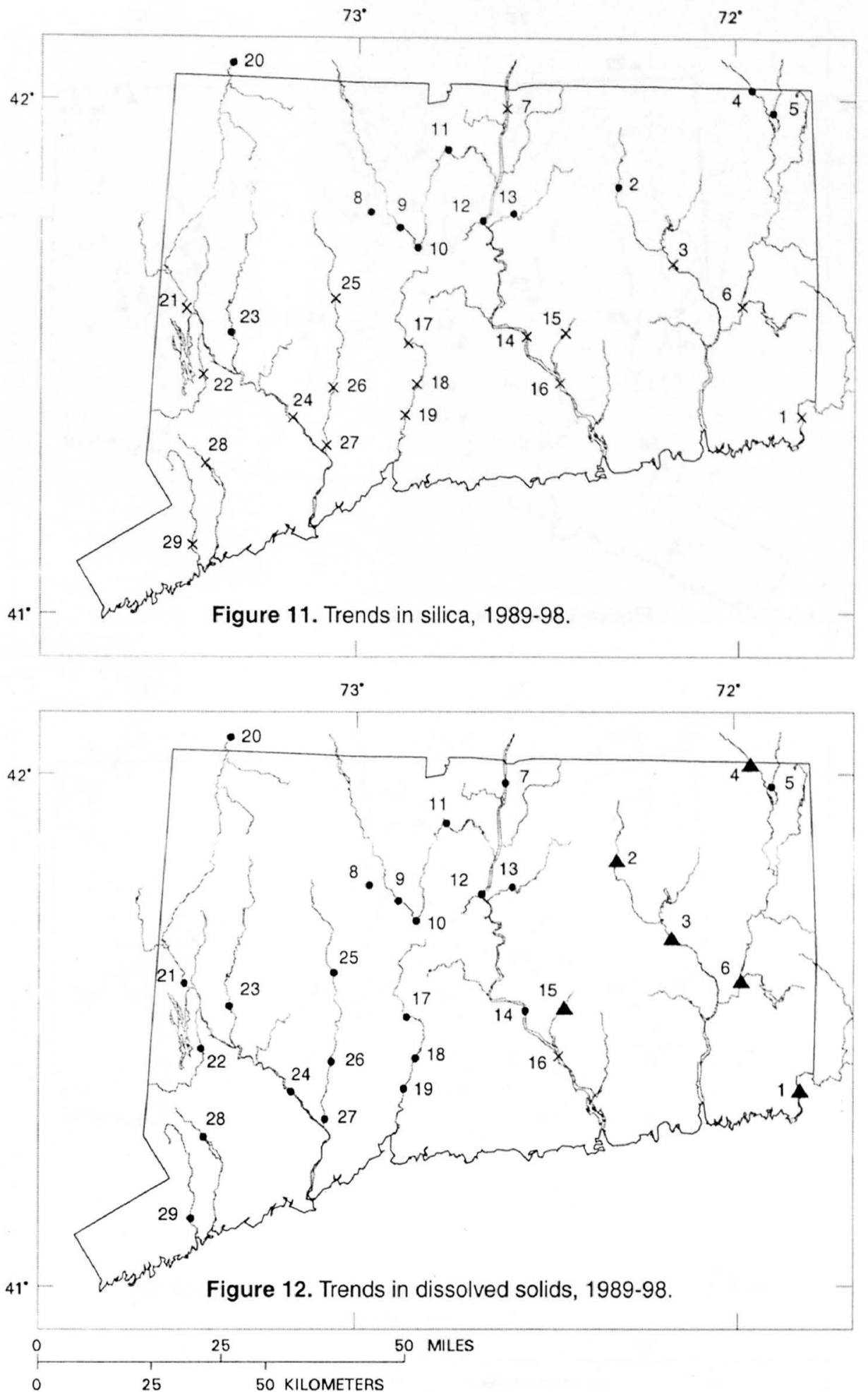

EXPLANATION

- Upward trend

- Downward trend

- No significant trend

$x$ Insufficient data for trend analysis 

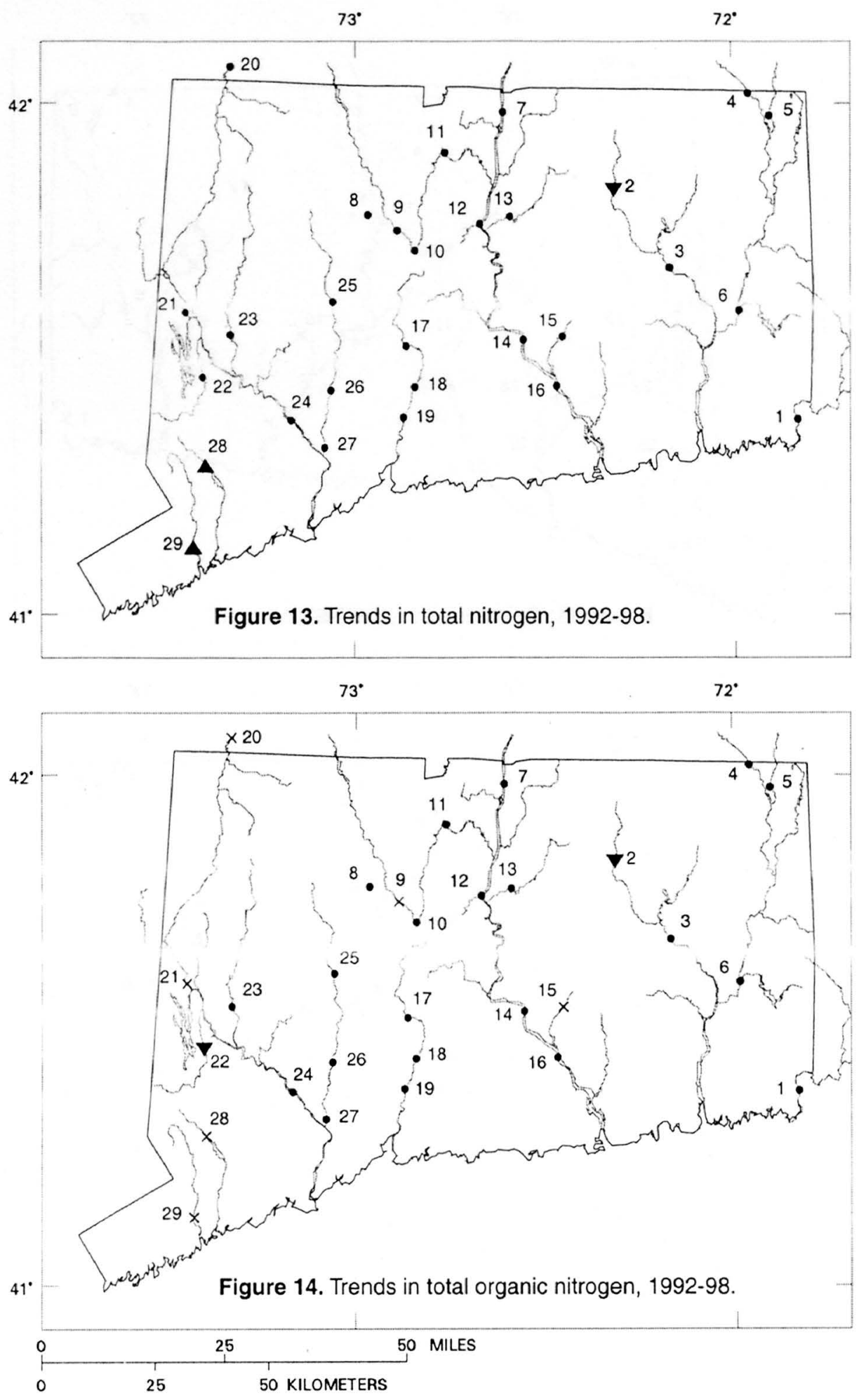

EXPLANATION

- Upward trend

- Downward trend

- No significant trend

$x$ Insufficient data for trend analysis 

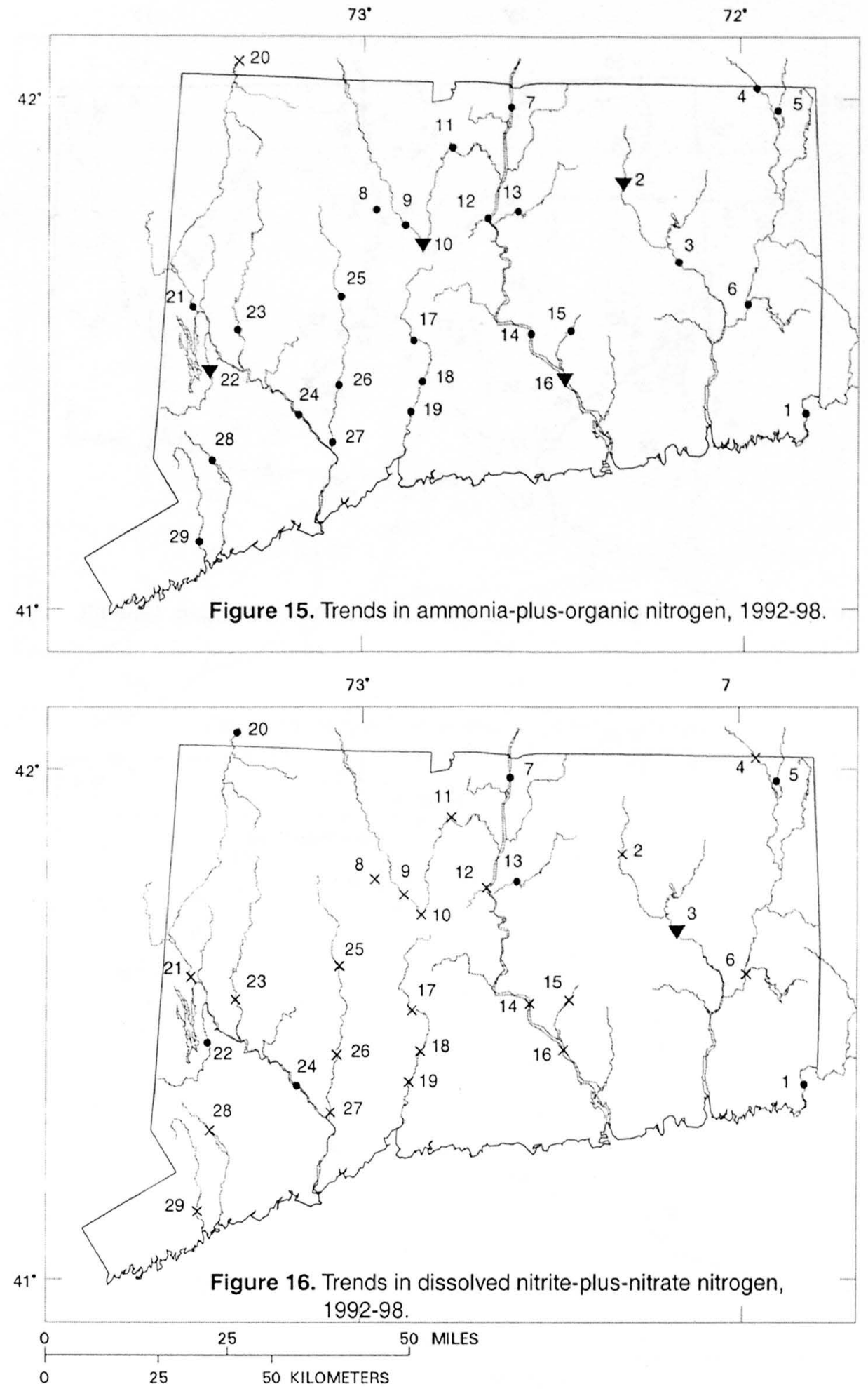

EXPLANATION

- Upward trend

จ Downward trend

- No significant trend

$\times$ Insufficient data for trend analysis 

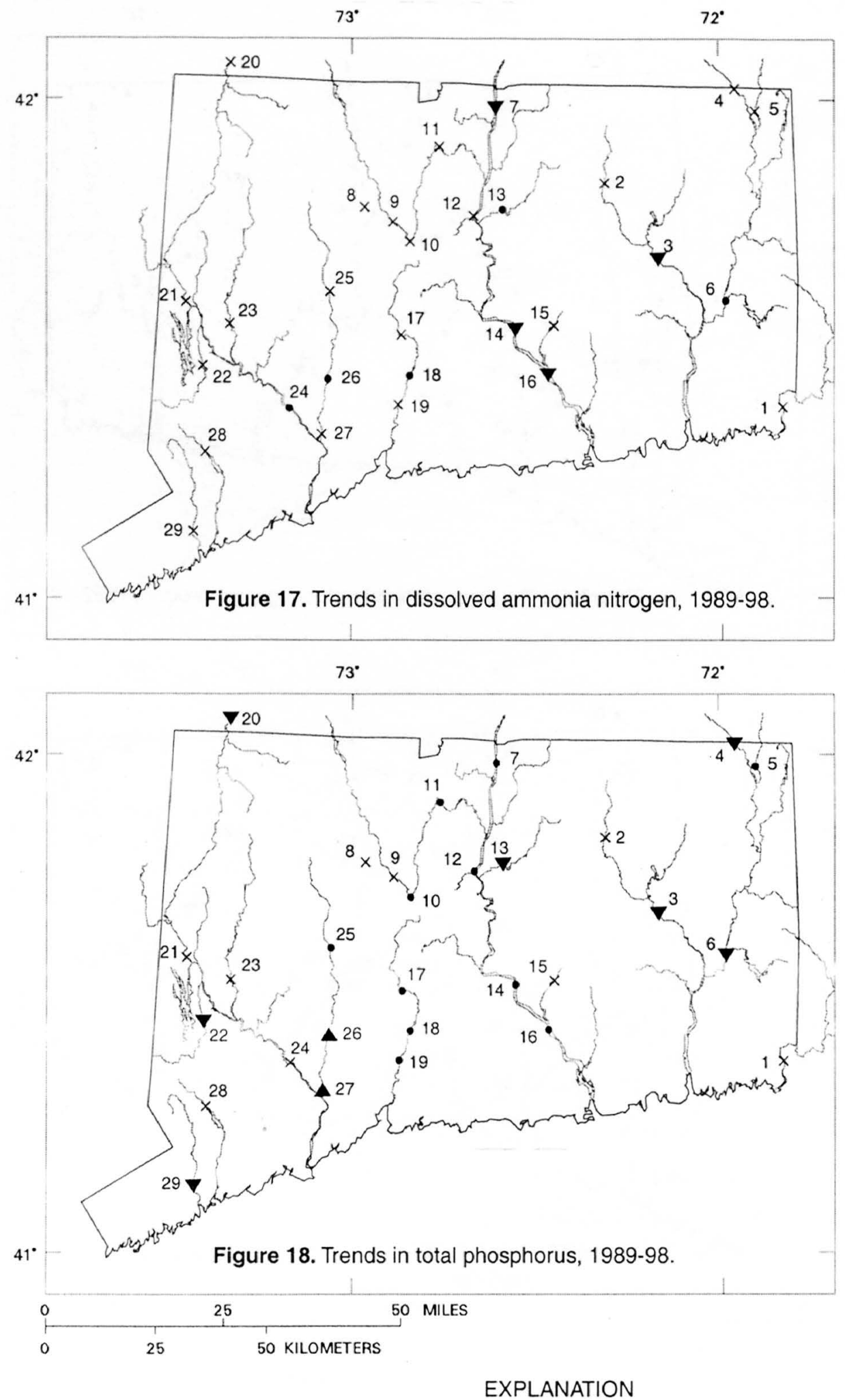

- Upward trend

v Downward trend

- No significant trend

$x$ Insufficient data for trend analysis 


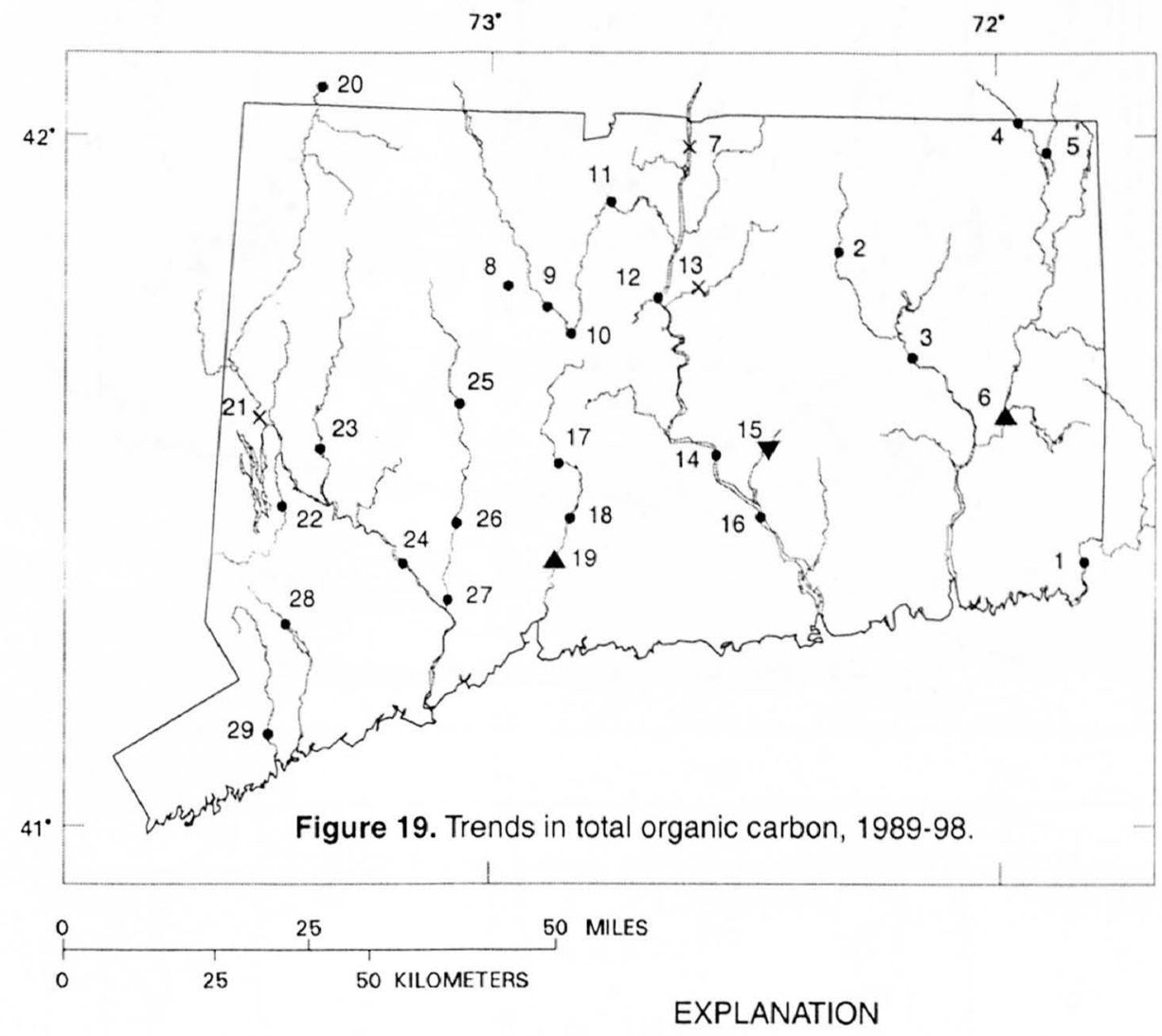

- Upward trend

$\nabla$ Downward trend

- No significant trend

$\times$ Insufficient data for trend analysis 

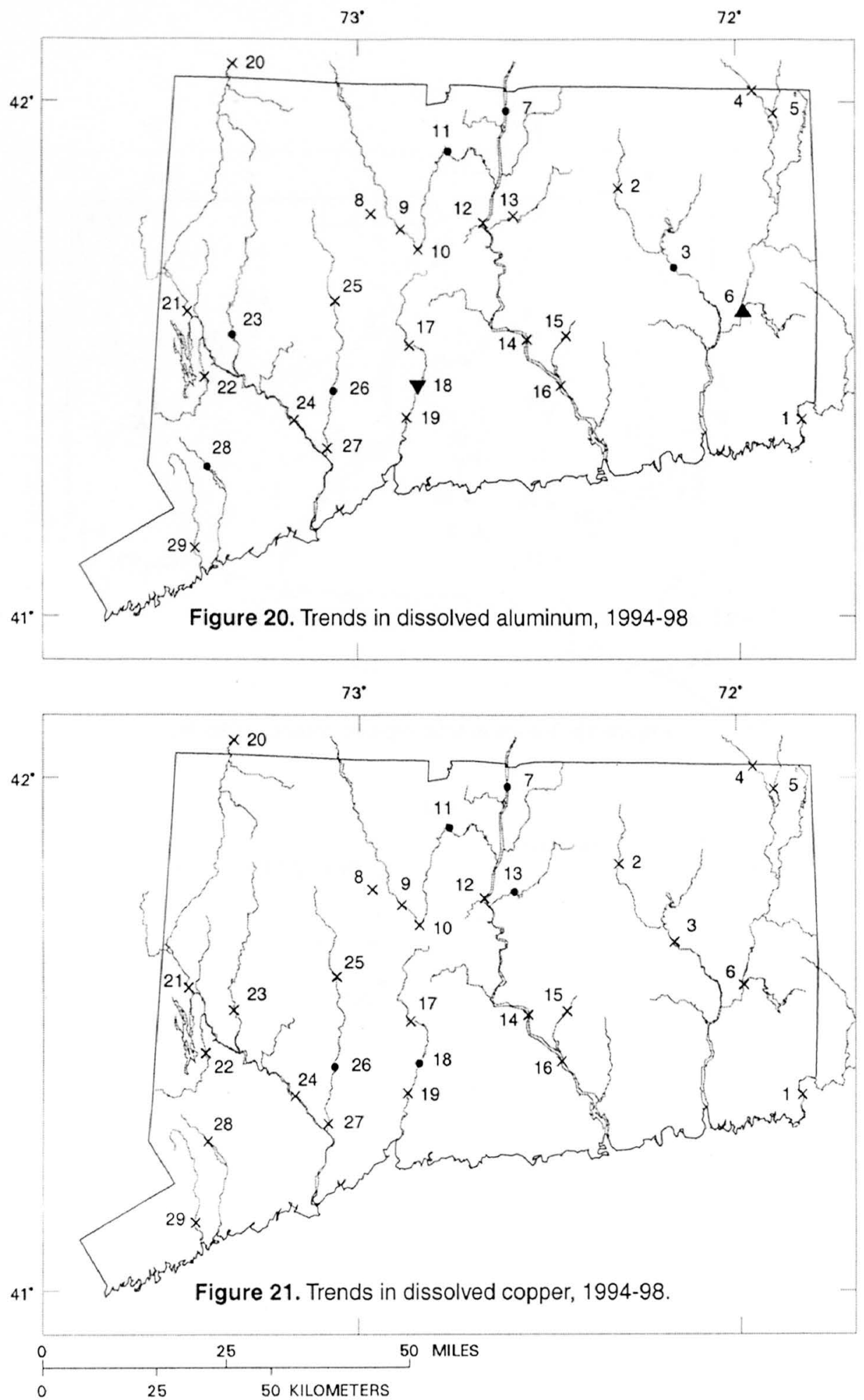

\section{EXPLANATION}

- Upward trend

v Downward trend

- No significant trend

$\times$ Insufficient data for trend analysis 

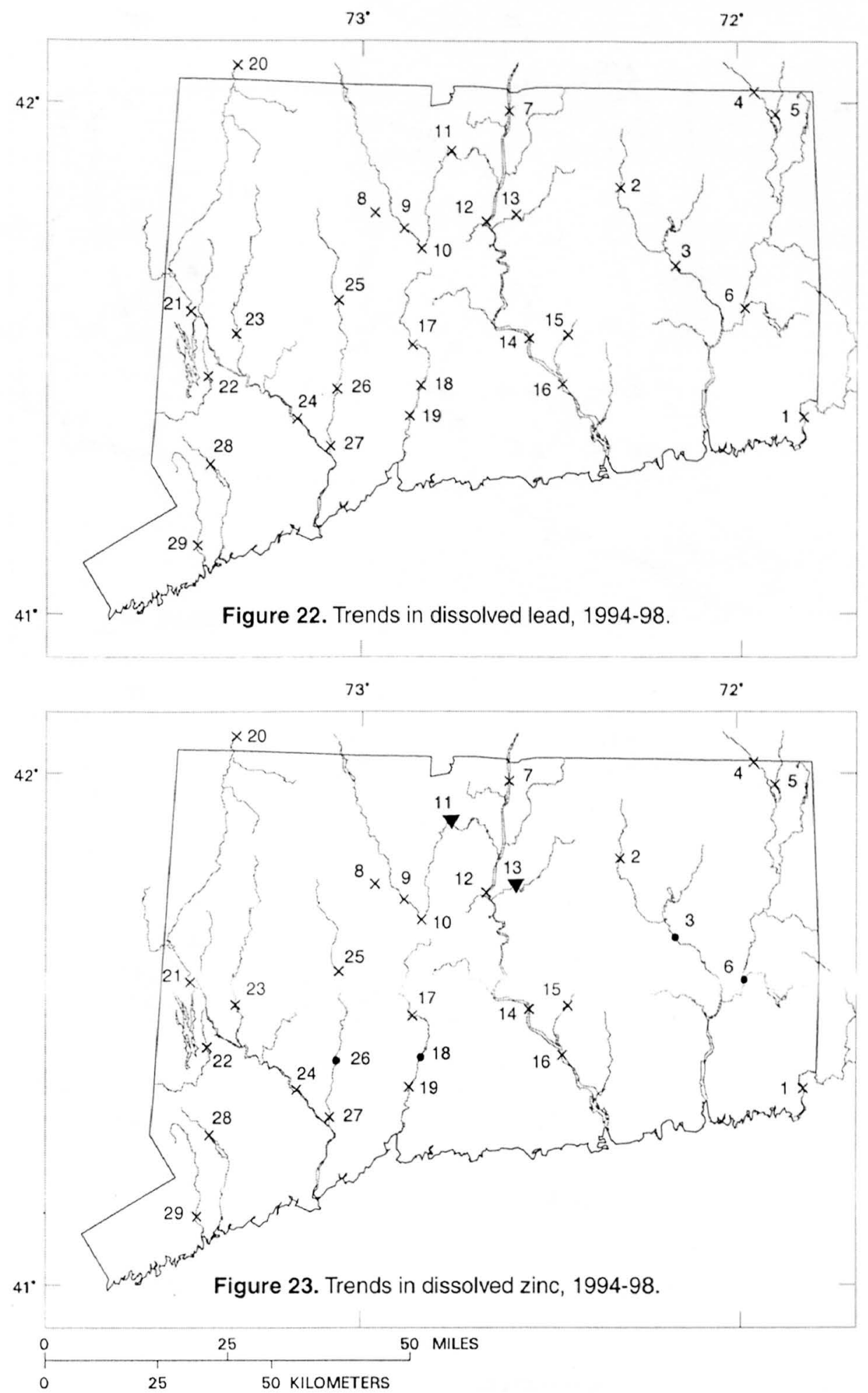

EXPLANATION

- Upward trend

$\nabla$ Downward trend

- No significant trend

$\times$ Insufficient data for trend analysis 

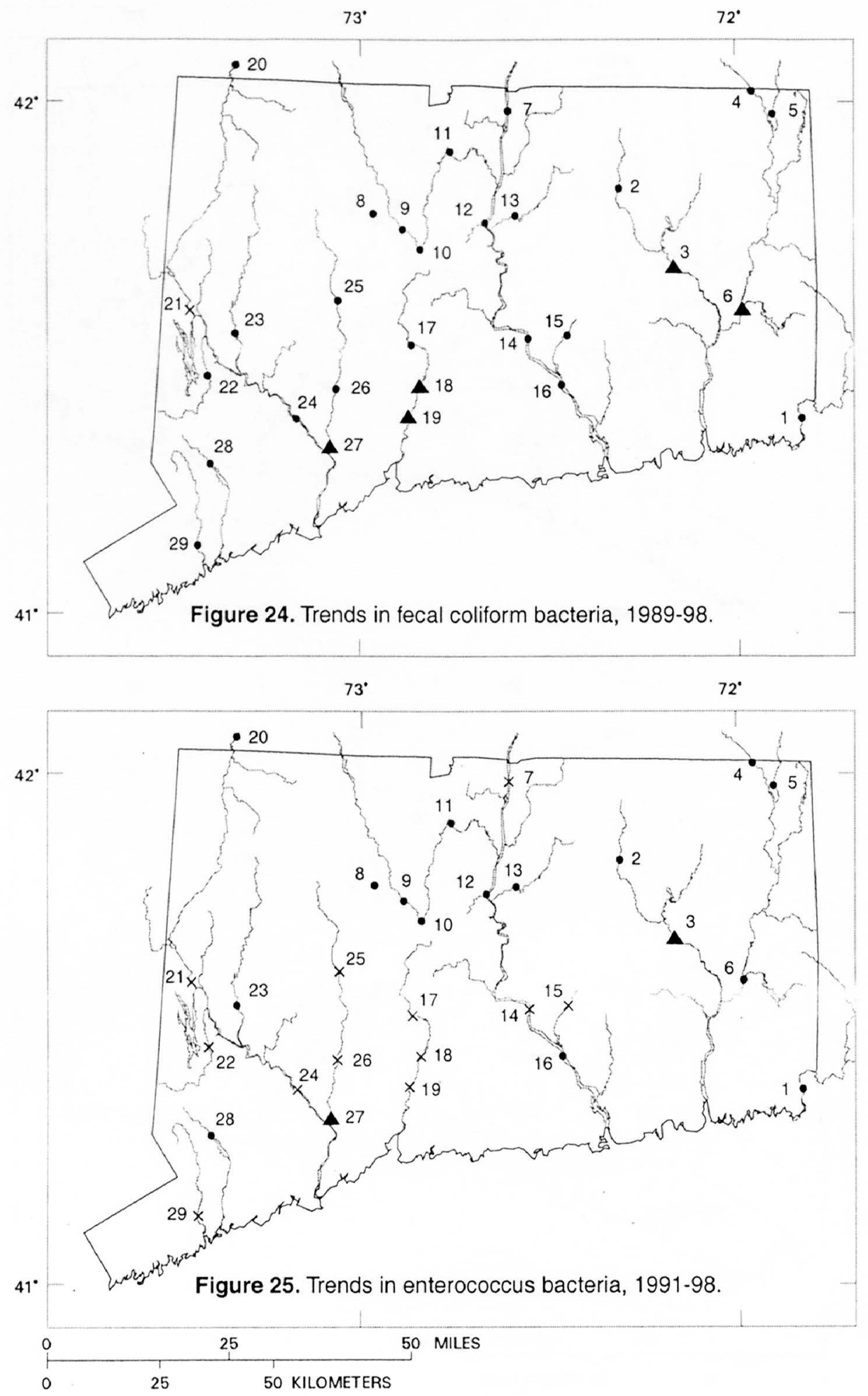

EXPLANATION

- Upward trend

- Downward trend

- No significant trend

$\times$ Insufficient data for trend analysis 

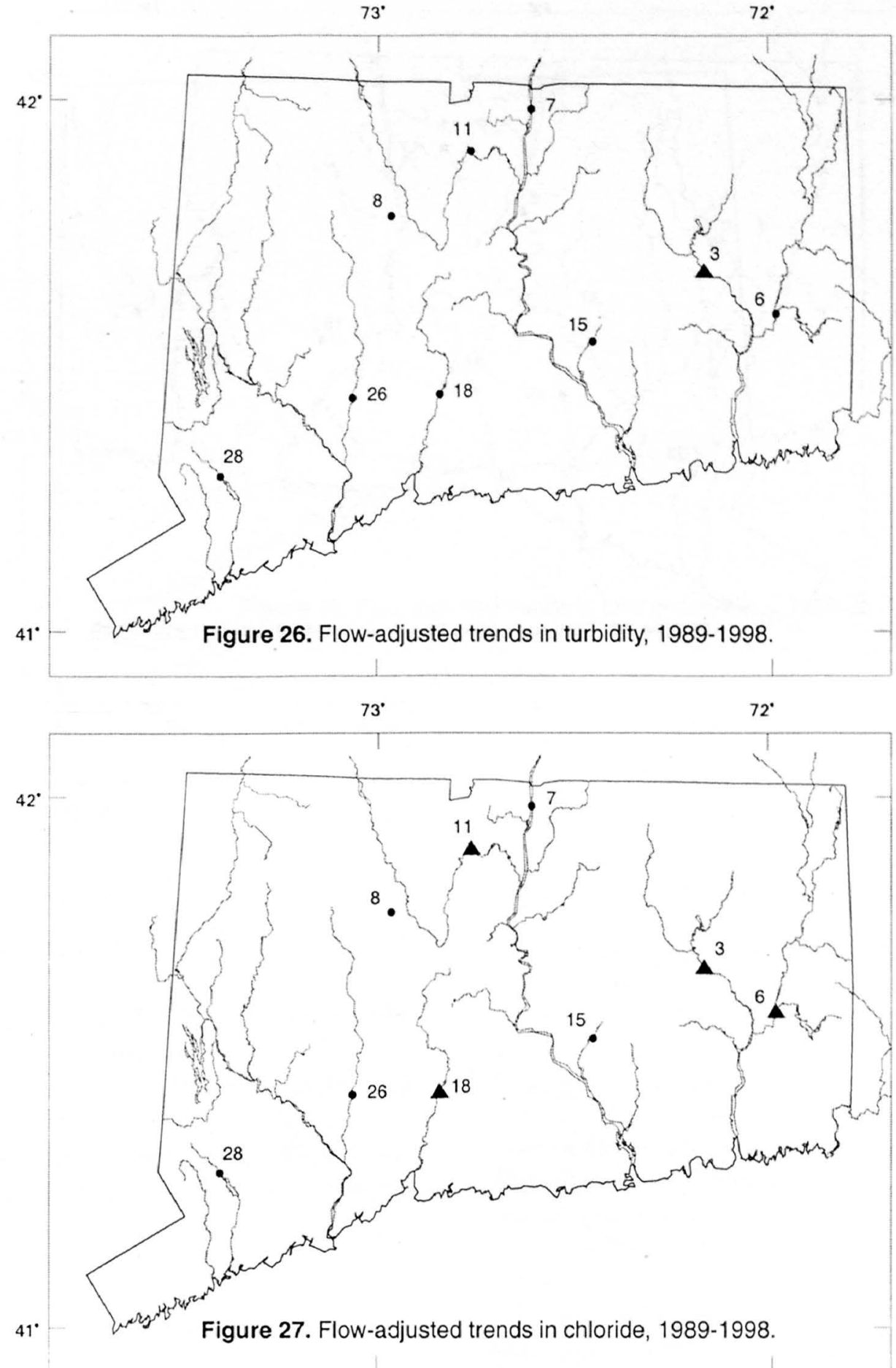

$\underbrace{0}_{0} \frac{25}{50 \text { KILOMETERS }}$ MILES

EXPLANATION

- Upward trend

จ Downward trend

- No significant trend

$x$ Insufficient data for trend analysis 

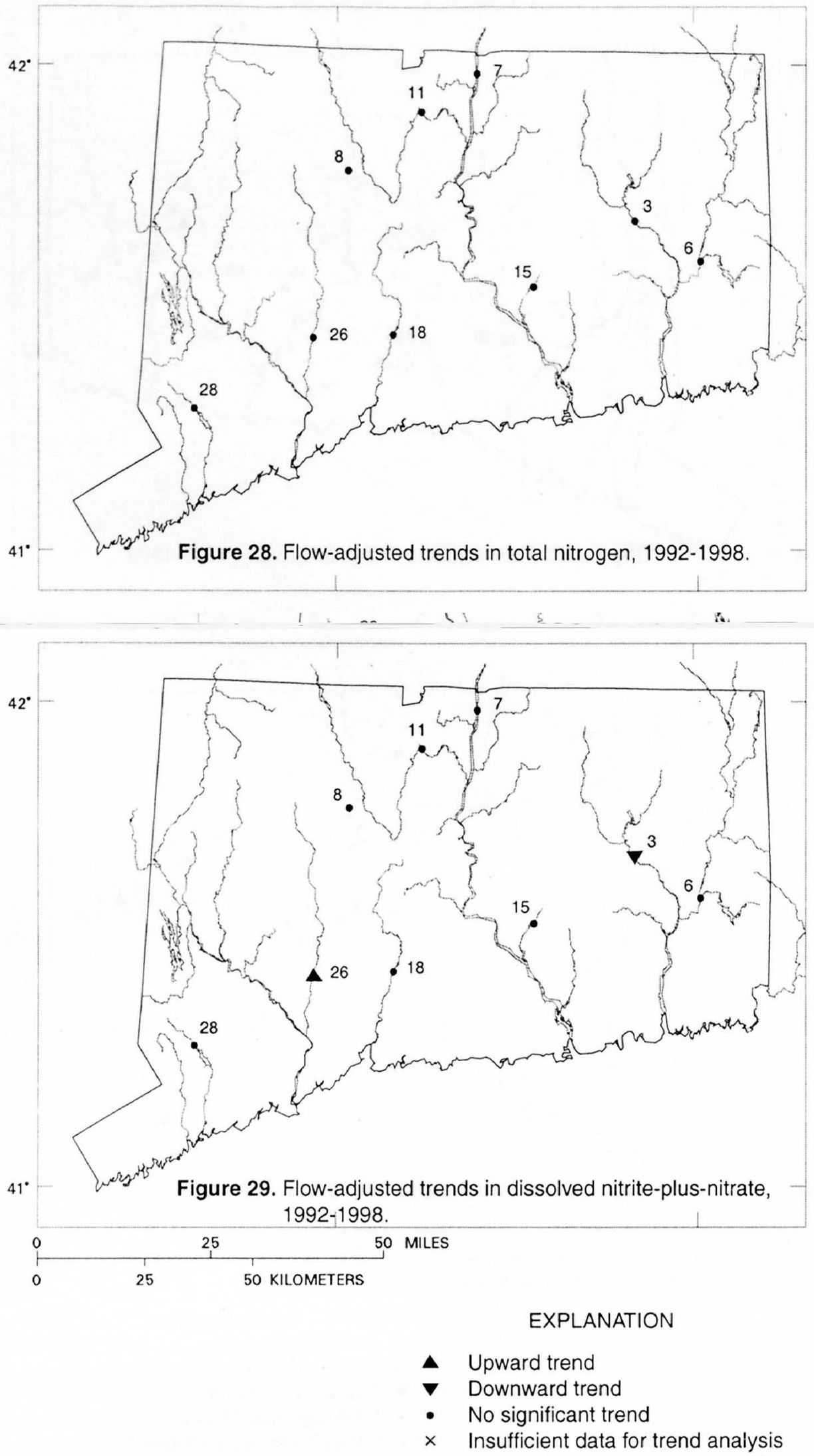


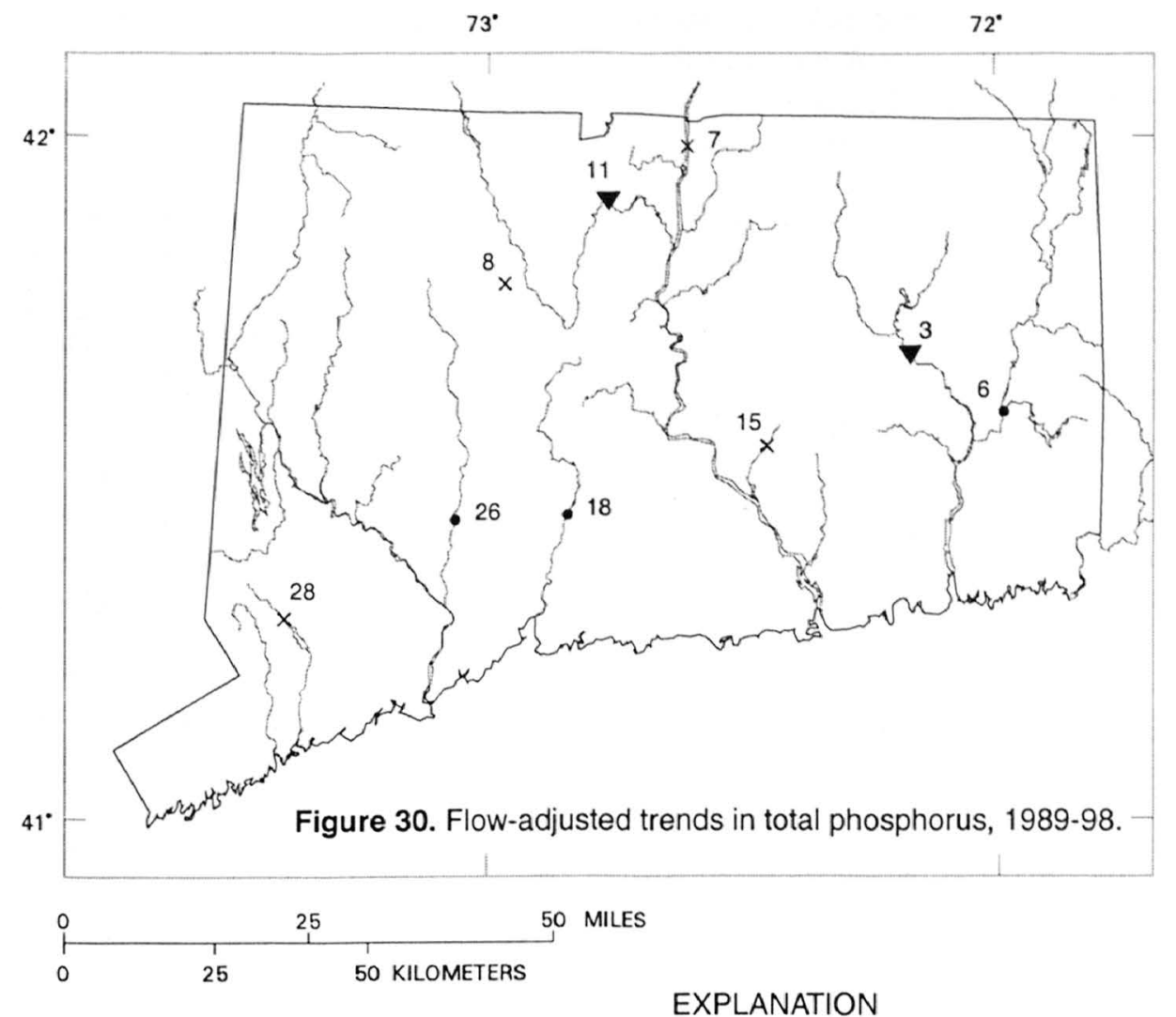

\section{EXPLANATION}

- Upward trend

$\nabla$ Downward trend

- No significant trend

$x$ Insufficient data for trend analysis

\section{SUMMARY}

Water-quality data for 29 monitoring stations on streams throughout Connecticut were analyzed for trends for 1989-98. Drainage basins for the 29 stations range in size from $4.10 \mathrm{mi}^{2}$ to $11,092 \mathrm{mi}^{2}$. Data for 22 constituents were evaluated for each station. Some stations lacked sufficient data for trend analysis for some constituents due to multiple changes in the sampling program and (or) laboratory methods during the study period.

The nonparametric seasonal Kendall test was selected for trend analysis to accommodate the nonnormal distribution of typical water-quality data sets. The test is designed to adjust for seasonal variability in water-quality conditions and was used in conjunction with flow-adjustment procedures at selected stations to remove the effects streamflow on water-quality variability.
The most geographically widespread trends detected were among the major chemical constituents. Concentrations of dissolved solids and chloride increased at 20 to 25 percent of the stations analyzed for trend, continuing the upward trends detected in an earlier study period of 1975-88. Increases in chloride concentrations took place in the central and eastern parts of the State, whereas dissolved solids concentrations increased only in the eastern part of the State. In contrast to increased concentrations during 1975-82, sulfate concentrations decreased statewide in all major drainage basins, with downward trends detected at 23 of 28 stations analyzed. Although declines in sulfate concentrations have been detected in other drainage basins in the eastern United States and may be related to declines in atmospheric deposition of sulfate, an earlier trend study in Connecticut detected numerous increases in sulfate concentration. Further interpretation would be required to link long-term changes in sulfate concentrations to changes in environmental factors. 
Trends for other major chemical constituents and physical properties typically were not numerous or geographically widespread, indicating that waterquality improvement or degradation generally has been a site-specific phenomenon. Specific conductance and turbidity showed upward trends at four stations scattered across the State, in contrast to the earlier study, which indicated a downward trend in turbidity statewide for the 1978-88 period. Trend analysis for dissolved oxygen as a percent of saturation and $\mathrm{pH}$ indicated no trend at 24 stations. The remaining five stations were split between upward and downward trends. Of the 29 stations analyzed for trend in alkalinity, 10 stations had downward trends during the study period. No trends in silica concentration were detected for the 11 stations with sufficient data for trend analysis.

Upward trends in nitrogen constituents were detected during 1975-88; however, no current statewide trends were found. Two upward trends and one downward trend were detected for total nitrogen. Total organic nitrogen had a downward trend at two stations, and total Kjeldahl nitrogen decreased at four stations. Dissolved nitrite-plus-nitrate nitrogen decreased at one of the eight stations analyzed for trend. Four downward trends were detected for dissolved ammonia nitrogen. Decreased total phosphorus concentrations were detected in both the 1975-88 and 1989-98 study periods. Concentrations of total phosphorus decreased at 7 of the 27 stations with sufficient data for trend anal$y$ sis and increased at 2 stations in the Naugatuck River. Total organic carbon concentration increased at 2 stations, decreased at 1 station, and showed no trend at 23 stations.

Trace metal concentrations changed very little during the 5-year period from 1994-98. Dissolved lead concentrations were highly censored (below detection limit) for all 11 stations evaluated, and no trend analysis was possible. The five stations with values above the detection limit for dissolved copper showed no significant trend for the period of study. Dissolved aluminum concentrations (analyzed at 8 stations) increased at the Quinebaug River at Jewett City and decreased in the Quinnipiac River at Wallingford. Dissolved zinc concentration decreased at two of the six stations analyzed for trend. Analysis of trends in dissolved trace metals were limited to the minimum acceptable time period, 5 years, because of significant changes in sampling protocols and laboratory methods during the early 1990's. Analysis of future data covering a longer period of record may yield useful information on trends in trace metals.

Increases in both fecal coliform and enterococcus bacteria were detected at a few stations on the Shetucket, Quinebaug, Quinnipiac, and Naugatuck Rivers. This result differs from the previous trend investigation (1975-88) that indicated scattered statewide downward trends in fecal coliform bacteria. Increases in bacterial colony concentrations indicate deterioration in the quality of water and may be related to changes in population distribution, which have resulted in new and increased wastewater discharges in urbanized areas and increased nonpoint-source runoff in urban, suburban, and less developed areas.

Results indicate that 80 percent of the 45 stationconstituent pairs had no significant flow-adjusted trend. The Shetucket River at South Windham had several flow-adjusted trends-upward trends in turbidity and chloride and downward trends in dissolved nitrite-plus-nitrate and total phosphorus. In the same way that unadjusted concentration trends are a useful management tool when combined with local water-quality standards, flow-adjusted concentration trends can be a integral part of understanding and managing human activity in a basin and its effect on water quality.

Additional analysis of the trend results described in this report would be useful to evaluate and understand the relation between trend results and changes in water-quality conditions. When changes and processes affecting water quality in a drainage basin are better understood, more effective management decisions can be made.

\section{REFERENCES CITED}

Alexander, R.B., Slack, J.R., Ludtke, A.S., Fitzgerald, K.K., and Schertz, T.L., 1996, Data from selected U.S. Geological Survey National Stream Water-Quality Monitoring Networks on CDROM: U.S. Geological Survey Open-File Report 96-337; also published as Digital Data Series DDS-37, CDROM (accessed online on $11 / 28 / 01$ at wwwvares.er.usgs.gov/wqn $96 \mathrm{~cd} / \mathrm{html} / \mathrm{wqn} /$ qasure/qa_lab.htm).

Alexander, R.B., Smith, R.A., and Schwarz, G.E., 1993, Correction of stream quality trends for the effects of laboratory measurement bias: Water Resources Research, v. 29, no. 11, p. 3821-3833. 
Cervione, M.A., Jr., Davies, B.S., 3rd, Bohr, J.R., and Hunter, B.W., 1990, Water resources data, Connecticut, water year 1989: U.S. Geological Survey Water-Data Report CT-89-1, $321 \mathrm{p}$.

Cervione, M.A., Jr., Davies, B.S., 3rd, Bohr, J.R., and Hunter, B.W., 1991, Water resources data, Connecticut, water year 1990: U.S. Geological Survey Water-Data Report CT-90-1, 265 p.

Cervione, M.A., Jr., Davies, B.S., 3rd, Bohr, J.R., and Hunter, B.W., 1992, Water resources data, Connecticut, water year 1991: U.S. Geological Survey Water-Data Report CT-91-1, 255 p.

Cervione, M.A., Jr., Davies, B.S., 3rd, Bohr, J.R., and Hunter, B.W., 1993, Water resources data, Connecticut, water year 1992, U.S. Geological Survey Water-Data Report CT-92-1, $261 \mathrm{p}$.

Cleveland, W.S., 1979, Robust locally weighted regression and smoothing scatterplots: Journal of American Statistical Association, v. 74, no. 368, p. 829-836.

Davies, B.S., 3rd, Bohr, J.R., and Hunter, B.W., 1994, Water resources data, Connecticut, water year 1993: U.S. Geological Survey Water-Data Report CT-93-1, 273 p.

Davies, B.S., 3rd, Bohr, J.R., Mullaney, J.R., and Morrison, Jonathan, 1995, Water resources data, Connecticut, water year 1994: U.S. Geological Survey Water-Data Report 94-1, 333 p.

Davies, B.S., 3rd, Bohr, J.R., Morrison, Jonathan, Kiesman, S.S., and Loos, D.A., 1996, Water resources data, Connecticut, water year 1995: U.S. Geological Survey Water-Data Report 95-1, 367 p.

Davies, B.S., 3rd, Morrison, Jonathan, Kiesman, S.S., and Colombo, M.J., 1997, Water resources data, Connecticut, water year 1996: U.S. Geological Survey WaterData Report 96-1, 275 p.

Davies, B.S., 3rd, Morrison, Jonathan, Bohr, J.R., and Sargent, T.C., 1998, Water resources data, Connecticut, water year 1997: U.S. Geological Survey Water-Data Report 97-1, $327 \mathrm{p}$.

Davies, B.S., 3rd, Morrison, Jonathan, Norris, J.R., and Organek, J.A., 1999, Water resources data, Connecticut, water year 1998: U.S. Geological Survey WaterData Report 98-1, 340 p.

Edwards, T.K., and Glysson, G.D., 1988, Field methods for measurement of fluvial sediment: U.S. Geological Survey Open-File Report 86-531, 118 p.

Fishman, M.J., and Friedman, L.C., eds., 1989, Methods for determination of inorganic substances in water and fluvial sediments: U.S. Geological Survey Techniques of Water-Resources Investigations, book 5, chap. Al, $545 \mathrm{p}$.

Friedman, L.C., and Erdmann, D.E., 1982, Quality assurance practices for the chemical and biological analyses of water and fluvial sediments: U.S. Geological Survey Techniques of Water-Resources Investigations, book 5 , chap. A6, $181 \mathrm{p}$.
Gilliom, R.J., Alley, W.M., and Gurtz, M.E., 1995, Design of the National Water Quality Assessment ProgramOccurrence and distribution of water-quality conditions: U.S. Geological Survey Circular 1112, 33 p.

Goerlitz, D.F., and Brown, Eugene, 1972, Methods for analysis of organic substances in water: U.S. Geological Survey Techniques of Water-Resources Investigations, book 5 , chap. A3, 40 p.

Greeson, P.E., Ehlke, T.A., Irwin, G.A., Lium, B.W., and Slack, K.V., eds., 1977, Methods for collection and analysis of aquatic biological and microbiological samples: U.S. Geological Survey Techniques of WaterResources Investigations, book 5, chap. A4, 332 p.

Guy, H.P., and Norman, V.W., 1970, Field methods for measurement of fluvial sediment: U.S. Geological Survey Techniques of Water-Resources Investigations, book 3 , chap. C2, 59 p.

Hay, L.E., and Campbell, J.P., 1990, Water-quality trends in New Jersey streams: U.S. Geological Survey WaterResources Investigations Report 90-4046, 297 p.

Helsel, D.R., and Hirsch, R.M., 1992, Statistical methods in water resources: Studies in Environmental Science 49, New York, Elsevier Science Publishers, 529 p.

Hirsch, R.M., Slack, J.R., and Smith, R.A., 1982, Techniques of trend analysis for monthly water quality data: Water Resources Research, v. 18, no. 1, p. 107-121.

Husar, R.B., Sullivan, T.J., and Charles, D.F., 1991, Historical trends in atmospheric sulfur deposition and methods for assessing long-term trends in surface water chemistry, in Charles, D.F., ed., Acidic deposition and aquatic ecosystems-Regional case studies: New York, Springer-Verlag, p. 48-92.

Insightful Corp., 1999, S-plus 2000-Modern statistics and advanced graphics, users guide: Cambridge, Mass., Insightful Corp., $558 \mathrm{p}$.

Lanfear, K.J., and Alexander, R.B., 1990, Methodology to derive water-quality trends for use by the National Water Summary Program of the U.S. Geological Survey: U.S. Geological Survey Open-File Report 90-0359, $10 \mathrm{p}$

Mast, M.A., and Turk, J.T., 1999, Environmental characteristics and water quality of hydrologic benchmark network stations in the eastern United States, 1963-95: U.S. Geological Survey Circular 1173-A, 158 p.

National Oceanic and Atmospheric Administration, 199099, Climatological data, annual summaries, New England 1989-98: Asheville, North Carolina, National Oceanic and Atmospheric Administration, v. 101-110, variously paged.

Patton, C.J., and Gilroy, E.J., 1999, U.S. Geological Survey nutrient preservation experiment-Experimental design, statistical analysis, and interpretation of analytical results: U.S. Geological Survey Water-Resources Investigations Report 98-4118,73 p. 
Patton, C.J., and Truitt, E.P., 2000, Methods of analysis by the U.S. Geological Survey National Water Quality Laboratory-Determination of ammonium plus organic nitrogen by a Kjeldahl digestion method and an automated photometric finish that includes digest cleanup by gas diffusion: U.S. Geological Survey Open-File Report 00-170, 31 p.

Petersen, J.C., 1992. Trends in streamwater-quality data in Arkansas during several time periods between 1975 and 1989: U.S. Geological Survey Water-Resources Investigations Report 92-4044, $182 \mathrm{p}$.

Ranzau, C.E., Jr., Davies, B.S., 3rd, Frick, T.W., and Organek, J.A., 2001, Water resources data, Connecticut, water year 2000: U.S. Geological Survey Water Resources Data Report CT-00, 333 p.

Ranzau, C.E., Jr., Frick, T.W., Norris, J.R., and Martin, J.W., 2000, Water resources data, Connecticut, water year 1999: U.S. Geological Survey Water Resources Data Report CT-99-1, $351 \mathrm{p}$.

Rodgers, John (compiler), 1985, Bedrock geological map of Connecticut: Connecticut Geological and Natural History Survey, Natural Resources Atlas Series Map, 2 sheets, scale 1:125,000.

Schertz, T.L., 1990, Trends in water-quality data in Texas: U.S. Geological Survey Water-Resources Investigations Report 89-4178, $177 \mathrm{p}$.

Schertz, T.L., Alexander, R.B., and Ohe, D.J., 1991, The computer program Estimate Trend (ESTREND), a system for the detection of trends in water-quality data: U.S. Geological Survey Water-Resources Investigations Report 91-4040, 63 p.

Skougstad, M.W., Fishman, M.J., Friedman, L.C., Erdmann, D.E., and Duncan, S.S., eds., 1979, Methods for determination of inorganic substances in water and fluvial sediments: U.S. Geological Survey Techniques of Water-Resources Investigations, book 5, chap. Al, $626 \mathrm{p}$.
Smith, R.A., Alexander, R.B., and Wolman, M.G., 1987, Analysis and interpretation of water-quality trends in major U.S. rivers, 1974-81: U.S. Geological Survey Water-Supply Paper 2307, $25 \mathrm{p}$.

Smith, R.A., Hirsch, R.N., and Slack, J.R., 1982, A study of trends in total phosphorus measurements at NASQAN stations: U.S. Geological Survey Water-Supply Paper $2190,34 \mathrm{p}$

Trench, E.C.T., 1996, Trends in surface-water quality in Connecticut, 1969-88: U.S. Geological Survey WaterResources Investigations Report 96-4161, $176 \mathrm{p}$.

Trench, E.C.T., 1999, Nutrient sources and loads in the Connecticut, Housatonic, and Thames River Basins, U.S. Geological Survey Water-Resources Investigations Report 99-4236, $66 \mathrm{p}$

U.S. Census Bureau, 1999, State population estimates, 1990-1999, accessed on 2/2/01 at URL:http://www. census.gov/population/www/estimates/statepop.html.

Vogelmann, J.E., Sohl, T.L., Campbell, P.V., and Shaw, D.M., 1998, Regional land cover characterization using LANDSAT thematic mapper data and ancillary data sources: Environmental Monitoring and Assessment, v. 51, p. $415-428$.

Wershaw, R.L., Fishman, M.J., Grabbe, R.R., and Lowe, L.E., 1987, Methods for the determination of organic substances in water and fluvial sediments: U.S. Geological Survey Techniques of Water-Resources Investigations: book 5, chap. A3, $80 \mathrm{p}$.

Zimmerman, M.J., Grady, S.J., Trench, E.C.T., Flanagan, S.M., and Nielsen, M.G., 1996, Water-quality assessment of the Connecticut, Housatonic, and Thames River basin study unit-Analysis of available data on nutrients, suspended sediments, and pesticides, 197292: Water-Resources Investigations Report 95-4203, $162 \mathrm{p}$. 


\section{APPENDIXES}



Appendix 1. Summary of trends for physical properties and major chemical constituents, 1989-98

[Values are trend slopes given in units per year (see table 2). Positive values are upward trends. Negative values are downward trends. $\mathrm{N}$, no significant trend; $\mathrm{C}$, censored values (greater than 5 percent); $\mathrm{m}$, more than 25 percent of values are missing; -, no data]

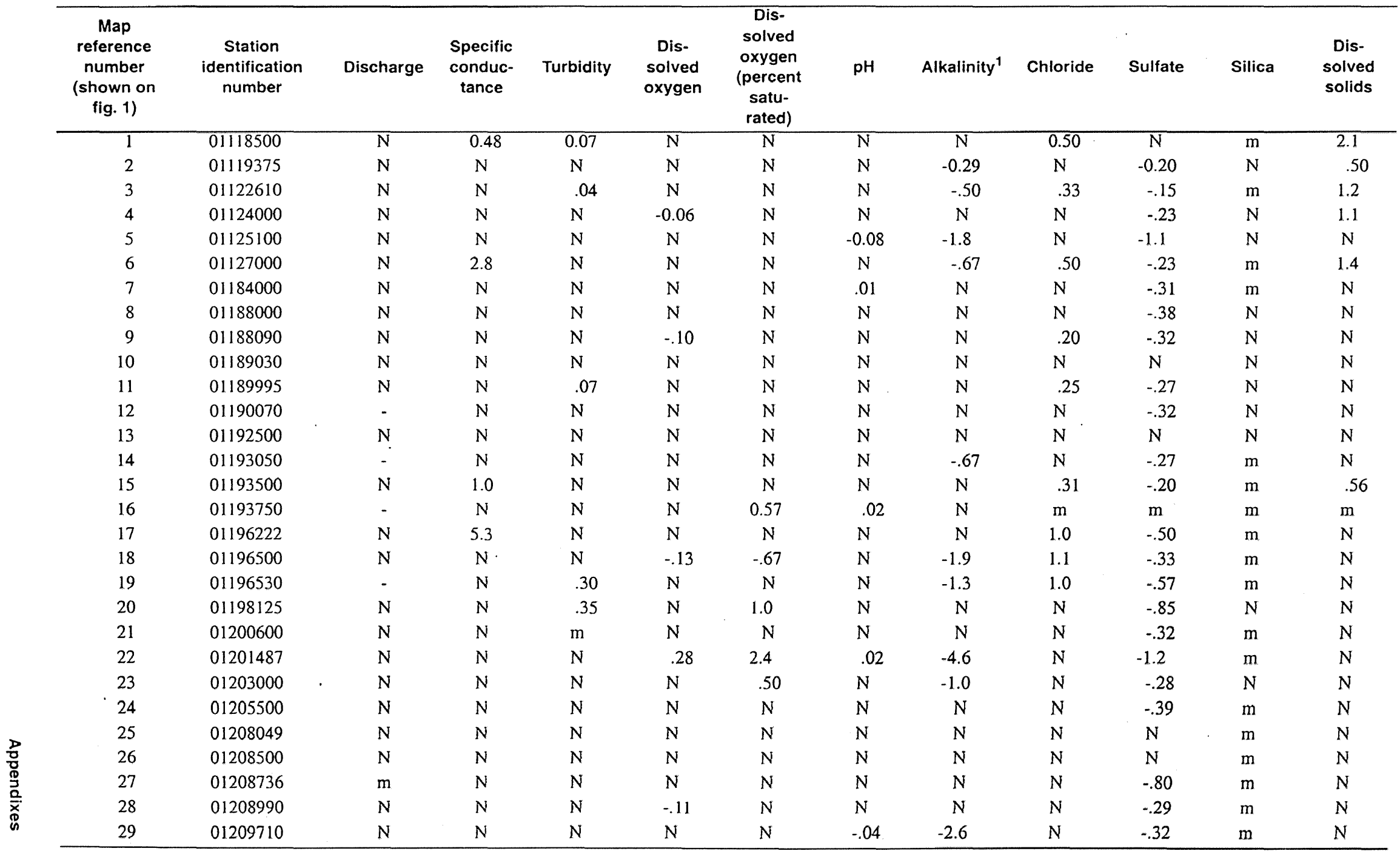

${ }^{1}$ Data are for water years $1992-98$. 
$\stackrel{\omega}{\infty}$ Appendix 2. Summary of trends for trace metals, nutrients, and bacteria, 1989-98

$\Rightarrow$ [Values are trend slopes given in units per year (see table 2). Positive values are upward trends. Negative values are downward trends. $N$, no significant trend; $C$, censored values (greater than 5 percent); $\overrightarrow{7}$ m, more than 25 percent of values are missing;,- no data]

\begin{tabular}{|c|c|c|c|c|c|c|c|c|c|c|c|c|c|c|}
\hline $\begin{array}{c}\text { Map } \\
\text { reference } \\
\text { number } \\
\text { (shown on } \\
\text { fig. 1) }\end{array}$ & $\begin{array}{c}\text { Station } \\
\text { identification } \\
\text { number }\end{array}$ & $\begin{array}{l}\text { Alumi- } \\
\text { num }^{7}\end{array}$ & Copper $^{1}$ & Lead $^{1}$ & Zinc ${ }^{1}$ & $\begin{array}{l}\text { Total } \\
\text { nitro- } \\
\text { gen }\end{array}$ & $\begin{array}{c}\text { Nitro- } \\
\text { gen, } \\
\text { organic } \\
\text { total as } \\
\mathrm{N}^{2}\end{array}$ & $\begin{array}{l}\text { Nitro- } \\
\text { gen, } \\
\text { ammo- } \\
\text { nia plus } \\
\text { organic } \\
\text { as } \mathrm{N}^{2}\end{array}$ & $\begin{array}{l}\text { Nitrite } \\
\text { plus } \\
\text { nitrate, } \\
\text { dis- } \\
\text { solved } \\
\text { as } \mathrm{N}^{2}\end{array}$ & $\begin{array}{l}\text { Ammo- } \\
\text { nia, } \\
\text { dissolved } \\
\text { as } N\end{array}$ & $\begin{array}{c}\text { Total } \\
\text { phos- } \\
\text { phorus }\end{array}$ & $\begin{array}{c}\text { Total } \\
\text { organic } \\
\text { carbon }\end{array}$ & $\begin{array}{c}\text { Fecal } \\
\text { coliform } \\
\text { bacteria }\end{array}$ & $\begin{array}{c}\text { Entero- } \\
\text { coccus } \\
\text { bacteria }\end{array}$ \\
\hline 1 & 01118500 & - & - & - & - & $N$ & $N$ & $N$ & $N$ & $\mathrm{~m}$ & $\mathrm{C}$ & $\mathrm{N}$ & $N$ & $N$ \\
\hline 2 & 01119375 & - & - & - & - & -0.04 & -0.02 & -0.02 & $\mathrm{~m}$ & $\mathrm{~m}$ & $\mathrm{C}$ & $\mathrm{N}$ & $N$ & $N$ \\
\hline 3 & 01122610 & $N$ & C & C & $\mathrm{N}$ & $N$ & $N$ & $N$ & -0.03 & -0.01 & -0.001 & $N$ & 14.6 & 7.5 \\
\hline 4 & 01124000 & - & - & - & - & $\mathrm{N}$ & $N$ & $N$ & $\mathrm{~m}$ & m & -.008 & $N$ & $N$ & $N$ \\
\hline 5 & 01125100 & - & - & - & - & $N$ & $N$ & $\mathrm{~N}$ & $N$ & $\mathrm{C}$ & $N$ & $N$ & $N$ & $N$ \\
\hline 6 & 01127000 & 4.1 & C & $\mathrm{C}$ & $N$ & $N$ & $\mathrm{~N}$ & $N$ & $\mathrm{~m}$ & $N$ & -.002 & 0.09 & 7.67 & $N$ \\
\hline 7 & 01184000 & $N$ & $N$ & $\mathrm{C}$ & $\mathrm{C}$ & $N$ & $N$ & $N$ & $N$ & -.01 & $\mathrm{~N}$ & $\mathrm{~m}$ & $\mathrm{~N}$ & $\mathrm{~m}$ \\
\hline 8 & 01188000 & $\mathrm{~m}$ & $\mathrm{C}$ & C & $\mathrm{C}$ & $N$ & $\mathrm{~N}$ & $N$ & $\mathrm{~m}$ & $\mathrm{~m}$ & C & $N$ & $\mathrm{~N}$ & $\mathrm{~N}$ \\
\hline 9 & 01188090 & - & - & - & - & $N$ & $\mathrm{~m}$ & $N$ & $\mathrm{~m}$ & $\mathrm{~m}$ & C & $N$ & $\mathrm{~N}$ & $N$ \\
\hline 10 & 01189030 & - & - & - & - & $N$ & $N$ & -.07 & $\mathrm{~m}$ & $\mathrm{~m}$ & $N$ & $N$ & $\mathrm{~N}$ & $N$ \\
\hline 11 & 01189995 & $N$ & $\mathrm{~N}$ & C & -0.36 & $N$ & $\mathrm{~N}$ & $N$ & $\mathrm{~m}$ & $\mathrm{~m}$ & $N$ & $N$ & $\mathrm{~N}$ & $N$ \\
\hline 12 & 01190070 & - & - & - & - & $N$ & $N$ & $N$ & $\mathrm{~m}$ & $\mathrm{~m}$ & $N$ & $N$ & $\mathrm{~N}$ & $N$ \\
\hline 13 & 01192500 & $\mathrm{~m}$ & $N$ & C & -2.2 & $N$ & $\mathrm{~N}$ & $N$ & $\mathrm{~N}$ & $N$ & -.03 & $\mathrm{~m}$ & $N$ & $N$ \\
\hline 14 & 01193050 & - & - & - & - & $\mathrm{N}$ & $\mathrm{N}$ & $N$ & $\mathrm{~m}$ & -.01 & $N$ & $N$ & $N$ & $\mathrm{~m}$ \\
\hline 15 & 01193500 & $\mathrm{~m}$ & $\mathrm{C}$ & C & $\mathrm{C}$ & $N$ & $\mathrm{~m}$ & $\mathrm{~N}$ & $\mathrm{~m}$ & $\mathrm{~m}$ & $\mathrm{C}$ & -.07 & $\mathrm{~N}$ & $\mathrm{~m}$ \\
\hline 16 & 01193750 & - & - & - & - & $\mathrm{N}$ & $\mathrm{N}$ & -.02 & $\mathrm{~m}$ & -.01 & $\mathrm{~N}$ & $N$ & $\mathrm{~N}$ & $N$ \\
\hline 17 & 01196222 & - & - & - & - & $N$ & $\mathrm{~N}$ & $N$ & $\mathrm{~m}$ & $\mathrm{~m}$ & $N$ & $N$ & $N$ & $\mathrm{~m}$ \\
\hline 18 & 01196500 & -5.0 & $N$ & C & $N$ & $N$ & $N$ & $N$ & $\mathrm{~m}$ & $N$ & $N$ & $N$ & 72.5 & $\mathrm{~m}$ \\
\hline 19 & 01196530 & - & - & - & - & $N$ & $N$ & $\mathrm{~N}$ & $\mathrm{~m}$ & $\mathrm{~m}$ & $\mathrm{~N}$ & .11 & 84.1 & $\mathrm{~m}$ \\
\hline 20 & 01198125 & - & - & - & - & $N$ & $\mathrm{~m}$ & $\mathrm{C}$ & $N$ & $\mathrm{C}$ & -.002 & $N$ & $N$ & $\mathrm{~N}$ \\
\hline 21 & 01200600 & - & - &. & - & $N$ & $\mathrm{~m}$ & $\mathrm{~N}$ & $\mathrm{~m}$ & $\mathrm{~m}$ & $\mathrm{C}$ & $\mathrm{m}$ & $\mathrm{m}$ & $\mathrm{m}$ \\
\hline 22 & 01201487 & - & - & - & - & $N$ & -.04 & -.05 & $\mathrm{~N}$ & $\mathrm{~m}$ & -.01 & $N$ & $\mathrm{~N}$ & $\mathrm{~m}$ \\
\hline 23 & 01203000 & $\mathrm{~N}$ & $\mathrm{C}$ & $\mathrm{C}$ & $\mathrm{C}$ & $N$ & $N$ & $\mathrm{~N}$ & $\mathrm{~m}$ & $\mathrm{~m}$ & $\mathrm{C}$ & $N$ & $N$ & $N$ \\
\hline 24 & 01205500 & - & - & - & - & $N$ & $N$ & $N$ & $N$ & $N$ & C & $N$ & $N$ & $\mathrm{~m}$ \\
\hline 25 & 01208049 & - & - & - & - & $N$ & $\mathrm{~N}$ & $N$ & $\mathrm{~m}$ & $\mathrm{~m}$ & $N$ & $N$ & $N$ & $\mathrm{~m}$ \\
\hline 26 & 01208500 & $\mathrm{~N}$ & $N$ & $\mathrm{C}$ & $N$ & $N$ & $N$ & $\mathrm{~N}$ & $\mathrm{~m}$ & $N$ & .02 & $\mathrm{~N}$ & $N$ & $\mathrm{~m}$ \\
\hline 27 & 01208736 & - & - & - & - & $N$ & $N$ & $\mathrm{~N}$ & $\mathrm{~m}$ & $\mathrm{~m}$ & .01 & $N$ & 1,000 & 191 \\
\hline 28 & 01208990 & $\mathrm{~N}$ & C & $\mathrm{C}$ & $\mathrm{C}$ & .02 & $\mathrm{~m}$ & $\mathrm{~N}$ & $\mathrm{~m}$ & $\mathrm{~m}$ & $\mathrm{C}$ & $\mathrm{N}$ & $N$ & N \\
\hline 29 & 01209710 & - & - & - & - & .04 & $\mathrm{~m}$ & $N$ & $\mathrm{~m}$ & $\mathrm{C}$ & -.003 & $N$ & $\mathrm{~N}$ & $\mathrm{~m}$ \\
\hline
\end{tabular}

${ }^{\mathrm{l}}$ Data are for water years $1994-98$

${ }^{2}$ Data are for water years $1992-98$

${ }^{3}$ Data are for water years $1991-98$. 
Appendix 3. Summary of flow-adjusted trends for selected water-quality constituents, 1989-98

[U, upward trend; D, downward trend; $N$, no significant trend; $C$, censored values (greater than 5 percent)]

\begin{tabular}{ccccccc}
\hline $\begin{array}{c}\text { Map reference } \\
\text { number } \\
\text { (shown on } \\
\text { fig. 1) }\end{array}$ & $\begin{array}{c}\text { Station identification } \\
\text { number }\end{array}$ & Turbidity & Chloride & $\begin{array}{c}\text { Total } \\
\text { nitrogen }{ }^{1}\end{array}$ & $\begin{array}{c}\text { Dissolved } \\
\text { nitrite plus } \\
\text { nitrate }\end{array}$ & $\begin{array}{c}\text { Total } \\
\text { phosphorus }\end{array}$ \\
\hline 3 & 01122610 & $\mathrm{U}$ & $\mathrm{U}$ & $\mathrm{N}$ & $\mathrm{D}$ & $\mathrm{D}$ \\
6 & 01127000 & $\mathrm{~N}$ & $\mathrm{U}$ & $\mathrm{N}$ & $\mathrm{N}$ & $\mathrm{N}$ \\
7 & 01184000 & $\mathrm{~N}$ & $\mathrm{~N}$ & $\mathrm{~N}$ & $\mathrm{~N}$ & $\mathrm{C}$ \\
8 & 01188000 & $\mathrm{~N}$ & $\mathrm{~N}$ & $\mathrm{~N}$ & $\mathrm{~N}$ & $\mathrm{C}$ \\
11 & 01189995 & $\mathrm{~N}$ & $\mathrm{U}$ & $\mathrm{N}$ & $\mathrm{N}$ & $\mathrm{D}$ \\
15 & 01193500 & $\mathrm{~N}$ & $\mathrm{~N}$ & $\mathrm{~N}$ & $\mathrm{~N}$ & $\mathrm{C}$ \\
18 & 01196500 & $\mathrm{~N}$ & $\mathrm{U}$ & $\mathrm{N}$ & $\mathrm{N}$ & $\mathrm{N}$ \\
26 & 01208500 & $\mathrm{~N}$ & $\mathrm{~N}$ & $\mathrm{~N}$ & $\mathrm{U}$ & $\mathrm{N}$ \\
28 & 01208990 & $\mathrm{~N}$ & $\mathrm{~N}$ & $\mathrm{~N}$ & $\mathrm{~N}$ & $\mathrm{C}$ \\
\hline
\end{tabular}

${ }^{1}$ Data are for $1992-98$. 
